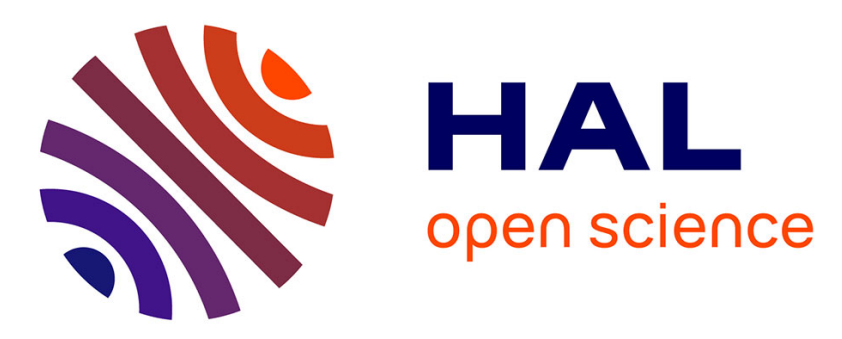

\title{
Protective effect of Rhus coriaria fruit extracts against hydrogen peroxide-induced oxidative stress in muscle progenitors and zebrafish embryos
}

Fadia Najjar, Francine Rizk, Gilles Carnac, Rim Nassar, Sara Jabak, Anatoly Petrovich Sobolev, Yara Bou Saada, Marwan El Sabban, Aline Hamade

\section{To cite this version:}

Fadia Najjar, Francine Rizk, Gilles Carnac, Rim Nassar, Sara Jabak, et al.. Protective effect of Rhus coriaria fruit extracts against hydrogen peroxide-induced oxidative stress in muscle progenitors and zebrafish embryos. PeerJ, 2017, 5, pp.e4144. 10.7717/peerj.4144 . hal-01833880

\section{HAL Id: hal-01833880 \\ https://hal.umontpellier.fr/hal-01833880}

Submitted on 12 Apr 2020

HAL is a multi-disciplinary open access archive for the deposit and dissemination of scientific research documents, whether they are published or not. The documents may come from teaching and research institutions in France or abroad, or from public or private research centers.
L'archive ouverte pluridisciplinaire HAL, est destinée au dépôt et à la diffusion de documents scientifiques de niveau recherche, publiés ou non, émanant des établissements d'enseignement et de recherche français ou étrangers, des laboratoires publics ou privés. 


\title{
Protective effect of Rhus coriaria fruit extracts against hydrogen peroxide- induced oxidative stress in muscle progenitors and zebrafish embryos
}

\author{
Fadia Najjar ${ }^{1}$, Francine Rizk ${ }^{1}$, Gilles Carnac ${ }^{2}$, Rim Nassar ${ }^{1}$, Sara Jabak ${ }^{1}$, \\ Anatoly Petrovich Sobolev ${ }^{3}$, Yara Bou Saada ${ }^{4}$, Marwan El Sabban ${ }^{5}$ and \\ Aline Hamade ${ }^{1}$ \\ ${ }^{1}$ Departments of Biology, Chemistry and Biochemistry, Laboratoire d'Innovation Thérapeutique, Faculty of \\ Sciences, Lebanese University, Fanar, Lebanon \\ ${ }^{2}$ PhyMedExp, University of Montpellier, INSERM U1046, CNRS UMR 9214, Montpellier, France \\ ${ }^{3}$ Istituto di Metodologie Chimiche, CNR, Laboratorio di Risonanza Magnetica Nucleare "Annalaura Segre", \\ Monterotondo, Rome, Italy \\ ${ }^{4}$ UMR 8256, CNRS, Université Pierre et Marie Curie, Paris, France \\ ${ }^{5}$ Department of Anatomy, Cell Biology and Physiological Sciences, American University of Beirut, Beirut, \\ Lebanon
}

Corresponding authors

Marwan El Sabban,me00@aub.edu.lb Aline Hamade,

aline.hamade@ul.edu.lb, alinehamade@gmail.com

Academic editor

Yegor Vassetzky

\section{ABSTRACT}

Background and Purpose. Oxidative stress is involved in normal and pathological functioning of skeletal muscle. Protection of myoblasts from oxidative stress may improve muscle contraction and delay aging. Here we studied the effect of $R$. coriaria sumac fruit extract on human myoblasts and zebrafish embryos in conditions of hydrogen peroxide-induced oxidative stress.

Study Design and Methods. Crude ethanolic 70\% extract (CE) and its fractions was obtained from sumac fruits. The composition of sumac ethyl acetate EtOAc fraction was studied by ${ }^{1} \mathrm{H}$ NMR. The viability of human myoblasts treated with $\mathrm{CE}$ and the EtOAc fraction was determined by trypan blue exclusion test. Oxidative stress, cell cycle and adhesion were analyzed by flow cytometry and microscopy. Gene expression was analyzed by qPCR.

Results. The EtOAc fraction ( $\mathrm{IC}_{50} 2.57 \mu \mathrm{g} / \mathrm{mL}$ ) had the highest antioxidant activity and exhibited the best protective effect against hydrogen peroxide-induced oxidative stress. It also restored cell adhesion. This effect was mediated by superoxide dismutase 2 and catalase. Pre-treatment of zebrafish embryos with low concentrations of the EtOAc fraction protected them from hydrogen peroxide-induced death in vivo. ${ }^{1} \mathrm{H}$ NMR analysis revealed the presence of gallic acid in this fraction.

Conclusion. Rhus coriaria extracts inhibited or slowed down the progress of skeletal muscle atrophy by decreasing oxidative stress via superoxide dismutase 2 and catalasedenendent mechanisms.

Keywords Sumac Rhus coriaria extract, Myoblast (LHCN-M2), Aging, NMR, Antioxidants, Zebrafish embryos 


\section{INTRODUCTION}

Skeletal muscles constitute about $40 \%$ of total body mass in humans and are essential for many functions, such as locomotion, postural maintenance, metabolic homeostasis, respiration, and thermoregulation (Frontera \& Ochala, 2015). The healthy state of muscles is critical for maintaining physical activity and overall energy balance; therefore muscle damage should be rapidly repaired. Precursor cells play a major role in muscle repair and renewal (Collins et al., 2005; Peault et al., 2007; Sacco et al., 2008; Zammit et al., 2004).

Skeletal muscle can be also affected by diseases. Muscular dystrophies (MDs) are a group of inherited disorders characterized by progressive muscle wasting and weakness. Related clinical manifestations vary in symptoms and severity, ranging from muscular fatigability, muscular weakness, and muscular pain, leading to restrictive respiratory insufficiency, motor disabilities and orthopedic problems (Emery, 2002; Flanigan, 2012). MDs are multifactorial pathologies in which nutritional, endocrine, metabolic and immunological components contribute to muscle depletion. In this context, skeletal muscle wasting is associated with increased oxidative stress (Moylan \& Reid, 2007; Powers \& Jackson, 2008).

Oxidative stress is induced by the imbalance between the generation and removal of reactive oxygen species (ROS). Radicals derived from oxygen represent the most important class of ROS (Halliwell \& Gutteridge, 2015; Sies, 2007; Sies \& Cadenas, 1985). ROS have long been associated with both physiology and pathology of skeletal muscle (Clanton, Zuo \& Klawitter, 1999; Reid et al., 1992); ROS level is crucial for the regulation of muscle contraction and is associated with muscle fatigue. Skeletal muscle is affected by the agerelated loss of function, whether directly or because of aging of other organs that supports its functionality (Bross, Storer \& Bhasin, 1999; Shefer et al., 2006). The "Free Radical Theory of Ageing" was described for the first time in 1956 (Harman, 1956) and the accumulation of oxidative damage to lipids, proteins and DNA occurring with age induces skeletal muscle aging (Hekimi, Lapointe \& Wen, 2011). Many studies suggest that enhancing the organism antioxidant capacities may delay the aging process (Gems \& Doonan, 2009; Willett, 2006). However, other studies showed that antioxidant supplements so far tested seem to offer no improvement over a well-balanced diet, possibly because of the choice of the substances tested or of an excessive dosage (Dolara, Bigagli e Collins, 2012).

Rhus coriaria L. (Tanner's Sumac or Sicilian Sumac) is a wild plant growing mainly in the Mediterranean countries, Iran and Afghanistan (Özcan \& Haciseferogullari, 2004). Extracts from the fruit of Rhus coriaria contain high levels of phenolic compounds, organic acids and terpenoids (Abu-Reidah et al., 2015). Furthermore, earlier studies showed that the fruits are rich in oleic and linoleic acids, vitamins as well as minerals (Gabr, El-Metwally \& Al-Ghadir, 2014; Kosar et al., 2007; Kossah et al., 2009; Powers \& Jackson, 2008).

Sumac extracts possess a potential antiviral, antimicrobial, antifungal, antioxidant and hypolipidemic activities (Ali-Shtayeh, Al-Assali \& Jamous, 2013; Aliakbarlu, Mohammadi \& Khalili, 2014; Kossah et al., 2013; Onkar, Mohammed \& Nida, 2011). Moreover, sumac is beneficial in the treatment of inflammation, diarrhea, oral diseases, dysentery and strokes (Rayne \& Mazza, 2007) and the antioxidant activity of fruit and leaves extracts from sumac has been demonstrated (Aliakbarlu, Mohammadi \& Khalili, 2014; Candan \& Sökmen, 
2004). Chakraborty et al. (2009) showed that sumac was able to protect human DNA, rat tissues and organs from oxidative stress-induced damage (Chakraborty et al., 2009). Antioxidant activities of sumac extracts may improve cell viability in several progressive diseases reinforcing the defenses against free radical species. The biological activity of sumac plants is attributed to their content of several antioxidant agents, phenolics compound being a major fraction (Gabr, El-Metwally \& Al-Ghadir, 2014; Kosar et al., 2007).

Zebrafish (Danio rerio) is a convenient animal model in investigating embryo-toxic and teratogenic compounds or food materials of potential value. The embryonic development of zebrafish is similar to that of the higher vertebrates, including humans (Howe et al., 2013; MacRae \& Peterson, 2003; Teraoka, Dong \& Hiraga, 2003; Zon, 1999). Thus, chemicals potentially toxic for zebrafish embryos could have similar effects on other vertebrate embryos. The features of this research model include similarities with mammals in physiological pathways, in functional domains of many genes associated with diseases, high rate of fecundity, external fertilization (allowing embryos to be exposed to drugs), rapid development, optical transparency of embryos and availability of genetic tools for research purposes (Alestrom, Holter \& Nourizadeh-Lillabadi, 2006; Ekker \& Akimenkko, 1991; Hong, 2009; Kimmel et al., 1995; Parng et al., 2002). A particular advantage for screening natural products such as herbal medicines, using this model, is the relatively small quantities of extracts used during the test.

Here we have assayed the activity of Sumac fruit extracts using free radical scavenging activity (DPPH) and the $\beta$ carotene-bleaching tests. The effects of these extracts in conditions of $\mathrm{H}_{2} \mathrm{O}_{2}$-induced oxidative were studied on cultured human myoblasts and zebrafish embryos.

\section{MATERIALS AND METHODS}

\section{Collection and preparation of sumac extracts}

Fresh fruit from Rhus coriaria L. plant was collected from South Lebanon, dried at room temperature until weight stabilization then pulverized.

The powdered sample (50 g) was mixed with 70\% ethanol and left at room temperature in the dark for 7 days with non-continuous stirring. The extract was filtered through paper filter and the ethanol was evaporated under reduced pressure. Residual water was lyophilized to obtain a crude extract (CE) stored at $4{ }^{\circ} \mathrm{C}$. The lyophilized powder was then taken up in $75 \mathrm{~mL}$ of water and undergone liquid-liquid extraction successively with several solvents: n-hexane, dichloromethane $\left(\mathrm{CH}_{2} \mathrm{Cl}_{2}\right)$ and ethyl acetate (EtOAc). The different fractions hex (oil), $\mathrm{CH}_{2} \mathrm{Cl}_{2}$ (oil), EtOAc (powder) and aqueous (aq, powder) were obtained after evaporation of the organic solvents and lyophilization of water.

\section{Determination of antioxidant activity DPPH free radicals scavenging activity}

The DPPH radical scavenging activity of the different extracts was measured according to the method of Yen \& Chen (1995) with slight modifications (Brand-Williams, Cuvelier \& Berset, 1995) and as described by Auezova et al. (2013). Serial dilutions of the sumac extracts were prepared in ethanol. The basic procedure was to add an aliquot $(1 \mathrm{~mL})$ of 
the test sample to $1 \mathrm{~mL}$ of DPPH solution prepared with ethanol $(0.15 \mathrm{mM})$. The mixture was vortexed for $1 \mathrm{~min}$ and then left to stand at room temperature for $30 \mathrm{~min}$ in the dark. The absorbance was measured at $517 \mathrm{~nm}$ using UV-Visible VWR spectrophotometer. The scavenging activity $(\mathrm{SA})$ was calculated as follows: $\mathrm{SA}(\%)=\left[1-\left(\mathrm{A}_{\text {sample }}-\mathrm{A}\right.\right.$ sample blank $\left.) / A_{\text {control }}\right] \times 100$. The sample solution $(1 \mathrm{~mL})$ plus ethanol $(1 \mathrm{~mL})$ was used as a sample blank and DPPH solution $(1 \mathrm{~mL})$ plus ethanol $(1 \mathrm{~mL})$ was used as a negative control. Catechin and ascorbic acid were used as positive controls. Stock solutions of catechin and ascorbic acid $(0.8 \mathrm{mg} / \mathrm{mL})$ were diluted with ethanol to give concentrations ranging from 1.5 to $20 \mu \mathrm{g} / \mathrm{mL}$. All measurements were performed in duplicate.

\section{$\beta$-carotene bleaching test}

The antioxidant activities of samples assayed by the linoleic acid- $\beta$-carotene system were measured according to the method described by Koleva et al. (2002) with slight modifications and as described by Auezova et al. (2013). Beta-carotene (10 mg) was dissolved in $10 \mathrm{~mL}$ chloroform, and $0.2 \mathrm{~mL}$ of this solution was mixed with linoleic acid (20 mg) and Tween-40 (200 mg). After removal of chloroform by evaporation under vacuum at $40^{\circ} \mathrm{C}, 50 \mathrm{~mL}$ of distilled water were added slowly to the semi-solid residue under vigorous stirring to form an emulsion, which was always prepared just before each experiment. A 96-well plate was loaded with $50 \mu \mathrm{L}$ per well of the samples or positive controls (catechin) and $200 \mu \mathrm{L}$ of the emulsion. One final concentration was tested $(50 \mu \mathrm{g} / \mathrm{mL})$, and ethanol was used as a blank. The absorbance values were read at $450 \mathrm{~nm}$ on a multi-well spectrophotometer (ELx800 Bio-Tek). The starting time of the reaction $(t=0 \mathrm{~min})$ is considered when the emulsion is added. Then, the plate was covered with a film and stored at $30^{\circ} \mathrm{C}$ for $3 \mathrm{~h}$; the absorbance was measured every $30 \mathrm{~min}$. The antioxidant activity of the extracts was evaluated as the percentage of inhibition of the bleaching of $\beta$-carotene using the following formula: $\left[\left(1-\left(\Delta\right.\right.\right.$ extract $_{t 0-t} / \Delta$ control $\left.\left._{t 0-t}\right)\right] * 100$. All samples were assayed in duplicates.

\section{NMR studies}

The NMR experiment was done as described elsewhere by Sobolev et al. (2014). Briefly, samples for NMR were prepared by dissolve in 5-10 mg of an extract in a deuterated solvent (methanol- $\mathrm{d}_{4}$ or the mixture of acetone- $\mathrm{d}_{6} / \mathrm{D}_{2} \mathrm{O}$ ). The NMR spectra of extracts were recorded at $27{ }^{\circ} \mathrm{C}$ on a Bruker AVANCE 600 NMR spectrometer operating at the proton frequency of $600.13 \mathrm{MHz}$ and equipped with a Bruker multinuclear $z$-gradient inverse probe head. ${ }^{1} \mathrm{H}$ spectra were acquired by adding 128 transients with a recycle delay of $3 \mathrm{~s}$. The experiments were carried out by using a $90^{\circ}$ pulse of $10 \mu \mathrm{s}, 32 \mathrm{~K}$ data points.

\section{Human myoblast cell culture}

LHCN-M2 is a line of human skeletal myoblasts derived from satellite cells from the pectoralis major muscle of a 41-year-old Caucasian male heart transplant donor (Zhu et al., 2007). Cells were grown as undifferentiated myoblasts in DMEM AQ media (Lonza, Basel, Switzerland) supplemented with 15\% Fetal Bovine Serum (FBS, Sigma-Aldrich, St Louis, MO, USA) and 1\% penicillin-streptomycin (Lonza, Basel, Switzerland) at $37{ }^{\circ} \mathrm{C}$ in a humidified atmosphere with $5 \% \mathrm{CO}_{2}$ and $95 \%$ air. The cells were usually split in a 1:3 ratio 
(33.33\%, passage 1) when they reached about $60 \%$ confluence. The culture was passaged by removing the media, washing with phosphate buffered saline (PBS, Sigma, St Louis, MO, USA) and separating the cells from their support with trypsin-EDTA (Gibco, New York, NY, USA). Cells were then centrifuged at $900 \mathrm{rpm}(150 \mathrm{~g})$ for $5 \mathrm{~min}$ and the pellet was suspended in $3 \mathrm{~mL}$ of fresh media in order to be seeded in a flask (Corning, New York, NY, USA) for passaging or well culture plates for the appropriate experiments. Doubling time for myoblast cell cultures is set to 10 to $15 \mathrm{~h}$ in order to avoid senescence.

\section{In vitro assay for cytotoxic activity}

The cytotoxicity of sumac was determined by the trypan blue exclusion test. Cells were seeded in a 24 -well-plate with a concentration of $20 \times 10^{3}$ cells/ well. The cells were left to adhere for $24 \mathrm{~h}$ before their exposition to different concentrations of the plant extracts ( 1 , 3, 10, 30, 60 and $90 \mu \mathrm{g} / \mathrm{mL}$ ) for $24 \mathrm{~h}, 48 \mathrm{~h}$ and $72 \mathrm{~h}$. At each time point, the media was removed; the cells were washed with PBS, split with trypsin-EDTA and centrifuged at 900 $\mathrm{rpm}$ for $5 \mathrm{~min}$. The pellet was suspended in $100 \mu \mathrm{l}$ fresh media. The cell suspension was diluted $(1: 1, \mathrm{v} / \mathrm{v})$ with trypan blue to reach $0.4 \%$. Each condition was done in duplicates and three independent experiments were performed.

The effect of sumac extracts on $\mathrm{H}_{2} \mathrm{O}_{2}$-induced oxidative stress was determined by trypan blue exclusion test as described above. Cells were treated with 1 and $3 \mu \mathrm{g} / \mathrm{mL}$ of CE and EtOAc fraction; $48 \mathrm{~h}$ after the treatments, $75 \mu \mathrm{M}$ of $\mathrm{H}_{2} \mathrm{O}_{2}$ (Sigma-Aldrich, St Louis, MO, USA) were added to the cells for $24 \mathrm{~h}$.

\section{ROS detection with dihydroethidium staining}

ROS production was monitored by fluorescent microscopy using dihydroethidium (DHE) staining. This assessment was obtained by measuring the ROS production in cell culture samples treated with different concentrations of EtOAc and crude extracts. After $48 \mathrm{~h}$ oxidative stress was induced with $75 \mu \mathrm{M}$ of $\mathrm{H}_{2} \mathrm{O}_{2}$ for $24 \mathrm{~h}$. Cells were then washed with PBS, $300 \mu \mathrm{L}$ of DHE $(10 \mu \mathrm{M})$ was added to each well and then incubated for $15 \mathrm{~min}$. After incubation, DHE was removed and replaced with $4 \%$ of formaldehyde for fixation. Finally, cells were observed with a confocal microscope (LSM).

\section{Cell cycle analysis by flow cytometry}

To assess the effect of sumac extracts on LHCN-M2 cell cycle distribution after inducing the oxidative stress, $4 \times 10^{4}$ cells were seeded in 12 -well plates. After $24 \mathrm{~h}$ of incubation, the media was removed and replaced with a new one containing $1 \mu \mathrm{g} \mathrm{ml}^{-1}$ of CE extract, 1 and $3 \mu \mathrm{g} \mathrm{ml}^{-1}$ of EtOAc fraction. After $48 \mathrm{~h}, 75 \mu \mathrm{M}$ of $\mathrm{H}_{2} \mathrm{O}_{2}$ was added; $24 \mathrm{~h}$ later, cells were treated with trypsin then centrifuged at 1,500 rpm for $5 \mathrm{~min}$. The pellet was washed with ice-cold PBS, centrifuged at 1,500 rpm for $5 \mathrm{~min}$, suspended with ice-cold PBS and fixed using absolute ethanol.

Fixed cells were treated for $1 \mathrm{~h}$ with $200 \mu \mathrm{g} / \mathrm{mL}$ of DNase-free RNase A. $500 \mu \mathrm{L}$ of PBS was added to $1 \mathrm{mg} / \mathrm{mL}$ of PI (Molecular Probes(C), Invitrogen, Paisley, UK). Cells were incubated for 10 to $15 \mathrm{~min}$ in the dark and later centrifuged in order to eliminate the non-stained cells. Cells were suspended in $200 \mu \mathrm{L}$ PBS in a flow tube (BD Falcon, Franklin Lakes, NJ, USA). A total of 10,000 gated events were acquired by flow cytometry 
(FACSAria, Becton Dickinson, Franklin Lakes, NJ, USA) representing the population of cells in each phase of the cell cycle. Subsequent data analysis and gating to determine the percentage of each cell cycle phase were done using FlowJo software. The experiment was repeated three times.

\section{Cell adhesion assay}

Myoblasts were either left untreated or pre-treated with 1 or $3 \mu \mathrm{g} / \mathrm{mL}$ of EtOAc fraction. After $48 \mathrm{~h}$, cells were subsequently trypsinised, seeded in 24 well plates and oxidative stress was induced using $75 \mu \mathrm{M}$ of $\mathrm{H}_{2} \mathrm{O}_{2}$ for $4 \mathrm{~h}$. Non-adherent cells were removed by washing with PBS and the adherent cells were trypsinised, collected and counted.

\section{RNA extraction and quantitative real-time PCR (qRT-PCR)}

LHCN-M2 cells were seeded in 6-well plates at a density of $8 \times 10^{4} .24$ h post-seeding, cells were either left untreated or pre-treated with 1 and $3 \mu \mathrm{g} / \mathrm{mL}$ of the EtOAc fraction. $48 \mathrm{~h}$ post-treatment, cells were treated with $75 \mu \mathrm{M}$ of $\mathrm{H}_{2} \mathrm{O}_{2}$. At the appropriate time point, the media was removed, cells were washed with PBS and the plates were stored at $-80^{\circ} \mathrm{C}$. Total RNA was extracted from the cells using Nucleospin RNA II kit (Macherey-Nagel, Düren, Germany) as per manufacturer's instructions. RNA purity and concentration were measured using NanoDrop ${ }^{\mathrm{TM}}$ spectrophotometer and then RNA was stored at $-20{ }^{\circ} \mathrm{C}$ for subsequent cDNA synthesis.

cDNA was prepared with $1 \mu \mathrm{g}$ of total RNA using Revertaid 1st strand cDNA synthesis kit (Fermentas, Thermo Scientific, Pittsburgh, PA, USA). The expression of various genes was analyzed by quantitative reverse transcriptase polymerase chain reaction (RT-qPCR) using the IQ SYBR GreenSupermix (Bio-Rad Laboratories, Pleasanton, CA, USA) in a CFX96 system (Bio-Rad Laboratories). Primers were designed using LightCycler design 2.0 (Roche Diagnostics, Indianapolis, IN, USA) and were tested for homology with other sequences using BLAST from NCBI database. Real-time PCR products were amplified using specific primers for myoD, myf5, myogenin, Gpx3, catalase, SOD2, and GAPDH (Table 1). PCR parameters consist of a pre-cycle at $95^{\circ} \mathrm{C}$ for $3 \mathrm{~min}$ followed by 40 cycles consisting of $95^{\circ} \mathrm{C}$ for $10 \mathrm{~s}, 60^{\circ} \mathrm{C}$ for $30 \mathrm{~s}$, and $72{ }^{\circ} \mathrm{C}$ for $30 \mathrm{~s}$. A final extension at $72^{\circ} \mathrm{C}$ for 5 min was then performed followed by a melting curve, starting at $55^{\circ} \mathrm{C}$ with a gradually increased temperature by steps of $0.5^{\circ} \mathrm{C}$ to arrive at $95^{\circ} \mathrm{C}$. The calculation method used was the standard curve method. The fluorescence threshold cycle value $(\mathrm{Ct})$ was obtained for each gene and normalized to that obtained for the GAPDH housekeeping gene in the same sample to normalize for discrepancies in sample loading. All experiments were carried out in duplicates and repeated three times.

\section{Origin and maintenance of parental zebrafish}

Adult wild-type zebrafish (Danio rerio) (Tübingen background; 3-5 cm) of both sexes were obtained from a specialized commercial supplier UMS AMAGEN CNRS INRA (France) and were used after ethical approval. Animals were housed in groups of 15 fishes in 5L thermostated tanks at $28 \pm 2{ }^{\circ} \mathrm{C}$, kept under constant chemical, biological and mechanical water filtration and aeration. Fish were maintained under a 14-10 h day/night photoperiod cycle, fed three times a day with commercial flakes (TetraMin ${ }^{\mathrm{TM}}$, Blacksburg, VA, USA) 
Table 1 Primers designed for real-time PCR experiment (retrieved from Primer-Blast $\left.{ }^{(\mathbb{R}}\right)$.

\begin{tabular}{ll} 
Gene of interest & Primer sequence \\
\hline myoD & F: $5^{\prime}$-ACAACGGACGACTTCTATGAC-3' \\
myf5 & R: $5^{\prime}$-TGCTCTTCGGGTTCAGGA-3' \\
myogenin & F: $5^{\prime}$-CATGCCCGAATGTAACAGTC-3' \\
& R: $5^{\prime}$-CCCAGGTTGCTCTGAGG-3' \\
GPx3 & F: $5^{\prime}$-ACCCCGCTTCTATGATGG-3' \\
& R: $5^{\prime}$-ACACCGACTTCCTCTTACACA-3' \\
SOD 2 & F: $5^{\prime}$-CGGGGACAAGAGAAGTCG-3' \\
& R: $5^{\prime}$-CCCAGAATGACCAGACCG-3' \\
Catalase & F: $5^{\prime}$-GGAGATGTTACAGCCCAGATAG-3' \\
& R: $5^{\prime}$-CAAAGGAACCAAAGTCACG-3' \\
GAPDH & F: $5^{\prime}$-CTGACTACGGGAGCCAC \\
& R: $5^{\prime}$-TGATGAGCGGGTTACACG \\
& F: $5^{\prime}$-TGGTGCTCAGTGTAGCCCAG-3' \\
& R: $5^{\prime}$-GGACCTGACCTGCCGTCTAG-3' \\
\hline
\end{tabular}

and supplemented with live brine shrimp. Embryos were obtained from natural spawning that was induced in the morning by turning on the light. A collection of embryos was completed within $30 \mathrm{~min}$. Embryos were maintained in a specific E3 medium $(34.8 \mathrm{~g} \mathrm{NaCl}$, $\left.1.6 \mathrm{~g} \mathrm{KCl}, 5.8 \mathrm{~g} \mathrm{CaCl}_{2} 2 \mathrm{H}_{2} \mathrm{O}, 9.78 \mathrm{~g} \mathrm{MgCl}_{2} 6 \mathrm{H}_{2} \mathrm{O}\right)$.

\section{Waterborne exposure of zebrafish embryos to sumac extracts and $\mathrm{H}_{2} \mathrm{O}_{2}$}

Tests on zebrafish eggs were performed according to OECD 203 (1992) and according to the OECD Guideline for Testing of Chemicals 210, Fish, Early Life Stage Toxicity Test (OECD, 1992). Fertilized eggs of zebrafish were sorted in the 12th stage (very late blastula), corresponding to 2.5-3-hour post fertilization (hpf). Only eggs of the same quality were used in the experiments. No spontaneous defects of development occurred in embryos after exceeding this stage of development and survival of embryos in the control conditions was $100 \%$.

Zebrafish embryos were transferred to 24 well plates, 10 embryos per well and three replicates per concentration for each of the evaluated endpoints were used in all the exposures. Embryos were maintained in $2 \mathrm{~mL} \mathrm{E3}$ medium and were exposed to 1, 3, 10, 30, 60, 90 and $120 \mu \mathrm{g} / \mathrm{mL}$ of sumac CE and EtOAc fraction. All bioassays included a negative control and a $0.3 \%$ DMSO control. Fish embryonic development was observed directly using a binocular microscope Leica. The following teratogenicity criteria were observed: incidence and extent of morphological abnormalities, hatching time and the number of hatched fish.

\section{Effect of sumac extracts on $\mathrm{H}_{2} \mathrm{O}_{2}$-induced oxidative stress}

4-6 hpf embryos were transferred to individual wells of a 24 well plate at a density of 10 embryos/well and maintained in $2 \mathrm{~mL}$ of embryos medium containing CE and EtOAc sumac extracts at different concentrations ( 1 and $3 \mu \mathrm{g} / \mathrm{mL}$ ) for $24 \mathrm{~h}$. Embryos were then treated with $\mathrm{H}_{2} \mathrm{O}_{2}$ for $2 \mathrm{~h}$ at a concentration of $2.10^{-2} \mathrm{~mol} / \mathrm{L}$. Vitamin $\mathrm{C}$ has been used as a 
Table 2 Antioxidant activity of Rhus coriara.

\begin{tabular}{lll} 
Sample & DPPH IC50 $(\mu \mathbf{g} / \mathbf{m L})$ & BCB Inhibition (\%) \\
\hline Crude $(\mathrm{CE})$ & $6.44 \pm 0,35$ & 47.01 \\
Hexane & $18.66 \pm 0,28$ & 36.75 \\
$\mathrm{CH}_{2} \mathrm{Cl}_{2}$ & $43.66 \pm 4,91$ & 30.94 \\
Ethyl acetate (EtOAc) & $2.57 \pm 0,51$ & 69.23 \\
Aqueous & $39.4 \pm 3,98$ & 31.62 \\
Catechin & $2.4 \pm 0,10$ & 64.10 \\
Ascorbic acid & $2.5 \pm 0,10$ & $\mathrm{Nd}$ \\
\hline
\end{tabular}

positive control at a concentration of $100 \mu \mathrm{M}$. Embryos viability was measured constantly using a stereoscope at intervals of $1 \mathrm{~h}$ after treatment.

\section{Statistical analysis}

Experiments studying the cell viability and cell cycle distribution were performed in triplicates. Results were expressed as mean values \pm SD and the corresponding error bars are displayed in the graphical plots. Statistical analysis was performed using the ANOVA test followed by post hoc tests of Duncan or Turkey for more precision. The study of the evolution of 2-time points was performed using the paired samples Student $t$-test. Differences were considered significant for $\mathrm{p}$ values less than 0.05. All analyses were done using the GraphPad Prism software (version 7.0).

\section{RESULTS}

\section{Sumac crude extract and an ethyl acetate fraction show in vitro antioxidant activity}

We used $70 \%$ ethanol to extract dried ground to powder seeds of sumac. The crude ethanolic extract was obtained with a yield of $42.40 \%$ relative to the dry plant. Through solvent-solvent partitioning with hexane, dichloromethane and EtOAc, four fractions were obtained from the crude extract. Among the fractions, the highest yield was observed in the aqueous fraction $(64.16 \%)$, followed by the EtOAc fraction $(33.53 \%)$, dichloromethane (1.24\%) and hexane (1.07\%) ones.

Antioxidant activity of sumac extracts was evaluated by DPPH free radical scavenging and $\beta$-carotene bleaching assays. The DPPH free radical method determined the antiradical power of antioxidants (Brand-Williams, Cuvelier \& Berset, 1995). For IC 50 values, sumac extracts depleted the initial DPPH concentration by $50 \%$ within $30 \mathrm{~min}$.

The free radical scavenging activities of the extract and fractions tested in this study are shown in Table 2. The highest antioxidant activity was exerted by the EtOAc fraction $\left(\mathrm{IC}_{50} 2.57 \pm 0,51 \mu \mathrm{g} / \mathrm{mL}\right)$. The other extracts had lower antioxidant activities: Crude ( $\mathrm{IC}_{50}$ $6.44 \pm 0,35 \mu \mathrm{g} / \mathrm{mL})>$ Hexane $\left(\mathrm{IC}_{50} 18.66 \pm 0,28 \mu \mathrm{g} / \mathrm{mL}\right)>$ Aqueous $\left(\mathrm{IC}_{50} 39.4 \pm 3,98\right.$ $\mu \mathrm{g} / \mathrm{mL})>\mathrm{CH}_{2} \mathrm{Cl}_{2}\left(\mathrm{IC}_{50} 43.66 \pm 4,91 \mu \mathrm{g} / \mathrm{mL}\right)$.

Results obtained after $\beta$-carotene bleaching assay were consistent with the data obtained with the DPPH test. Thus, EtOAc extract showed the greatest antioxidant activity $(69.23 \%$ of inhibition of $\beta$-carotene bleaching at $50 \mu \mathrm{g} / \mathrm{mL}$ ) superior to the inhibition capacity 
of the catechin positive control (64.10\%) at the same concentration. Crude extracts also exhibited a significant antioxidant power (47.01\%). Aqueous, hexane and $\mathrm{CH}_{2} \mathrm{CL}_{2}$ extracts showed the weakest activity potential in this assay (Table 2).

\section{Sumac extract is enriched in gallic acid and gallotanins}

The composition of sumac ethyl acetate extract was studied by ${ }^{1} \mathrm{H}$ NMR. The most intense ${ }^{1} \mathrm{H}$ NMR signals at $7.08 \mathrm{ppm}$ (in deuterated methanol) in the aromatic compounds' region 7.0-7.7 ppm belongs to gallic acid. The major part of the remaining signals from the phenolic fraction can be assigned to gallotannins. This assignment was confirmed by the comparison of our data with those from the literature where several components of gallotannin fraction were chemically synthesized and characterized by NMR (Sylla et al., 2015). To compare our and published NMR data, the extract was dissolved in acetone$\mathrm{d}_{6} / \mathrm{D}_{2} \mathrm{O}(9: 1)$ mixture. Apart from aromatic signals, gallotannins show characteristic signals of esterified $\beta$-glucose at $6.30 \mathrm{ppm}(\mathrm{CH}-1), 6.03 \mathrm{ppm}(\mathrm{CH}-3), 5.67 \mathrm{ppm}(\mathrm{CH}-2$, and $\mathrm{CH}-4)$ and $4.57 \mathrm{ppm}\left(\mathrm{CH}-5\right.$ and $\left.\mathrm{CH}_{2}-6\right)$. Other signals in 4.5-1.0 ppm region belong to malic acid (Fig. 1).

\section{Sumac fractions are not cytotoxic at low concentrations on LHCN-M2 cells}

In vitro cytotoxicity test is mainly performed to screen for potentially toxic compounds that affect basic cellular functions. We measured cytotoxicity of the EtOAc fraction and crude extracts of sumac on human myoblast cell line LHCN-M2 using trypan blue exclusion assay.

Neither of the two extracts was cytotoxic at low concentrations $(<10 \mu \mathrm{g} / \mathrm{mL})$, but the growth of LHCN-M2 cells decreased with increasing concentrations of each of these two extracts in a dose-dependent manner (Fig. 2).

As shown in Fig. 2A, at 60 and $90 \mu \mathrm{g} / \mathrm{mL}$ of crude extract, the maximal inhibition of cell viability reached 80 and $100 \%$ respectively after 24,48 and $72 \mathrm{~h}$ of treatment $(p \leq 0.001)$. The treated-LHCN-M2 cells displayed a dose-dependent decrease in cell survival after 48 $\mathrm{h}$ and $72 \mathrm{~h}$ (for CE 1; 3; 10 and $30 \mu \mathrm{g} / \mathrm{mL}$ ). Similarly, treatment of LHCN-M2 cells with EtOAc fraction significantly decreased cell viability reaching 80 to $100 \%$ when used at 30 , 60 and $90 \mu \mathrm{g} / \mathrm{mL}$ after 24, 48 and $72 \mathrm{~h}$ post-treatment (Fig. 2B).

Using data obtained from the trypan blue assay, $\mathrm{IC}_{50}$ was found to be higher than 30 $\mu \mathrm{g} / \mathrm{mL}$ for the CE extract and higher than $10 \mu \mathrm{g} / \mathrm{mL}$ of the EtOAc fraction. Concentrations lower than $10 \mu \mathrm{g} / \mathrm{mL}$ for the $\mathrm{CE}$ and EtOAc fraction were used in subsequent assays.

The crude extract and the ethyl acetate fraction protect human myoblast from $\mathrm{H}_{2} \mathrm{O}_{2}$-induced oxidative stress at low concentration

LHCN-M2 cells were pre-incubated with or without CE extracts and EtOAc fraction (1 and $3 \mu \mathrm{g} / \mathrm{mL}$ ) for $48 \mathrm{~h}$ then exposed to $75 \mu \mathrm{M} \mathrm{H}_{2} \mathrm{O}_{2}$ for $24 \mathrm{~h}$ at $37^{\circ} \mathrm{C}$. This concentration of $\mathrm{H}_{2} \mathrm{O}_{2}$ significantly decreased cell viability $(p<0,001)$. Pre-treatment with the $\mathrm{CE}$ and the EtOAc fraction significantly protected LHCN-M2 cells from $\mathrm{H}_{2} \mathrm{O}_{2}$-induced oxidative stress when used at low concentrations ( 1 and $3 \mu \mathrm{g} / \mathrm{mL}$ ), similarly to the positive control (1 and 3) $\mu \mathrm{g} / \mathrm{mL}$ Vitamin C (VitC) (Fig. 3A). In parallel, the Fig. 3B showed the protective 


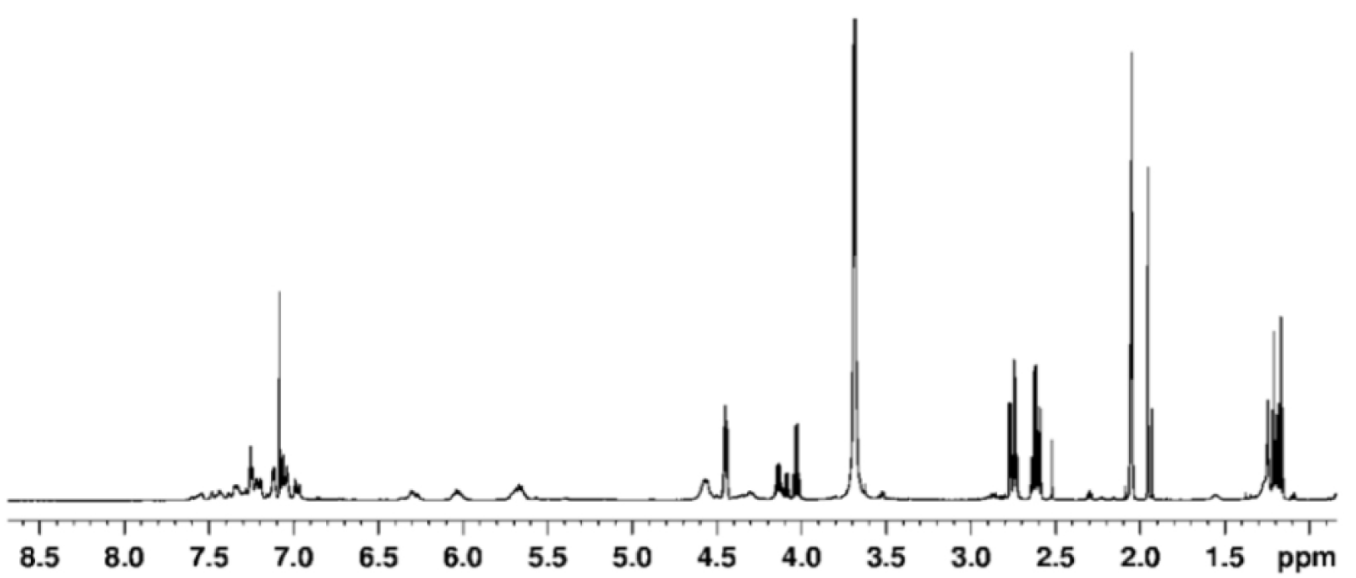

B

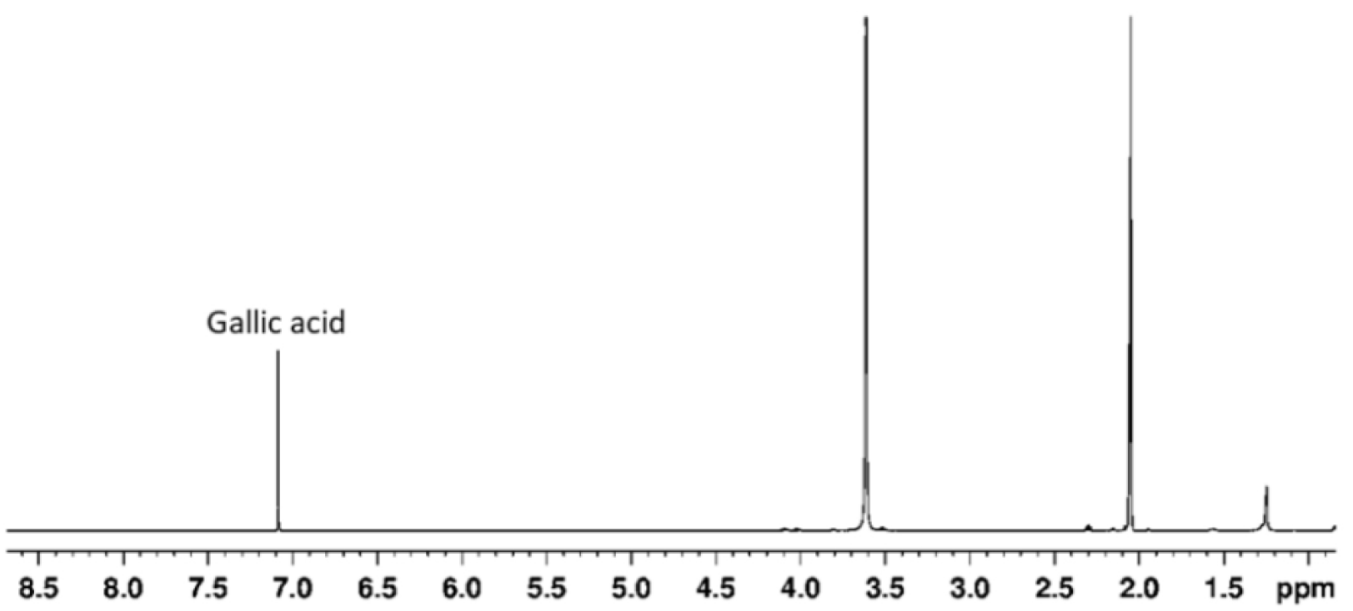

Figure 1 (A) ${ }^{1} \mathrm{H}$ NMR spectrum of sumac ethylacetate extract in acetone- $\mathrm{d}_{6} / \mathrm{D}_{2} \mathrm{O}(9: 1) \mathrm{v} / \mathrm{v}$ mixture, (B) ${ }^{1} \mathrm{H}$ NMR spectrum of gallic acid in acetone- $\mathrm{d}_{6} / \mathrm{D}_{2} \mathrm{O}(9: 1) \mathrm{v} / \mathrm{v}$ mixture.

antioxidant effect of gallic acid at low concentration $(0.3 \mu \mathrm{M})$, and this activity decreased due to the cytotoxic effect of this product at a higher concentration, superior to $10 \mu \mathrm{M}$.

In our study, DHE staining was used to assess the levels of ROS after treatment of LHCN-M2 cells with low concentrations of sumac extracts. As shown in Fig. 4, treatment with $75 \mu \mathrm{M} \mathrm{H}_{2} \mathrm{O}_{2}$ induced accumulation of ROS in untreated cells (high red fluorescence) whereas cells without $\mathrm{H}_{2} \mathrm{O}_{2}$ showed a low intensity of fluorescence (control). On the other hand, $1 \mu \mathrm{g} / \mathrm{mL}$ of CE extract, 1 and $3 \mu \mathrm{g} / \mathrm{mL}$ of EtOAc fraction significantly decreased the ROS level as compared to the $\mathrm{H}_{2} \mathrm{O}_{2}$-treated control $(p<0.05)$. The EtOAc fraction ( 1 and $3 \mu \mathrm{g} / \mathrm{mL}$ ) exhibit the highest antioxidant effect on LHCN-M2 cells (Fig. 4I).

\section{Sumac extracts reduce cell cycle arrest in myoblasts subjected to oxidative stress}

Figure 5 illustrated the effect of sumac extracts on cell cycle arrest in LHCN-M2 cells treated with $\mathrm{H}_{2} \mathrm{O}_{2}$. Twenty percent of LHCN-M2cells treated with $\mathrm{H}_{2} \mathrm{O}_{2}$ underwent cell cycle arrest, whereas pretreatment of LHCN-M2 cells with 1 and $3 \mu \mathrm{g} / \mathrm{mL}$ of EtOAc 

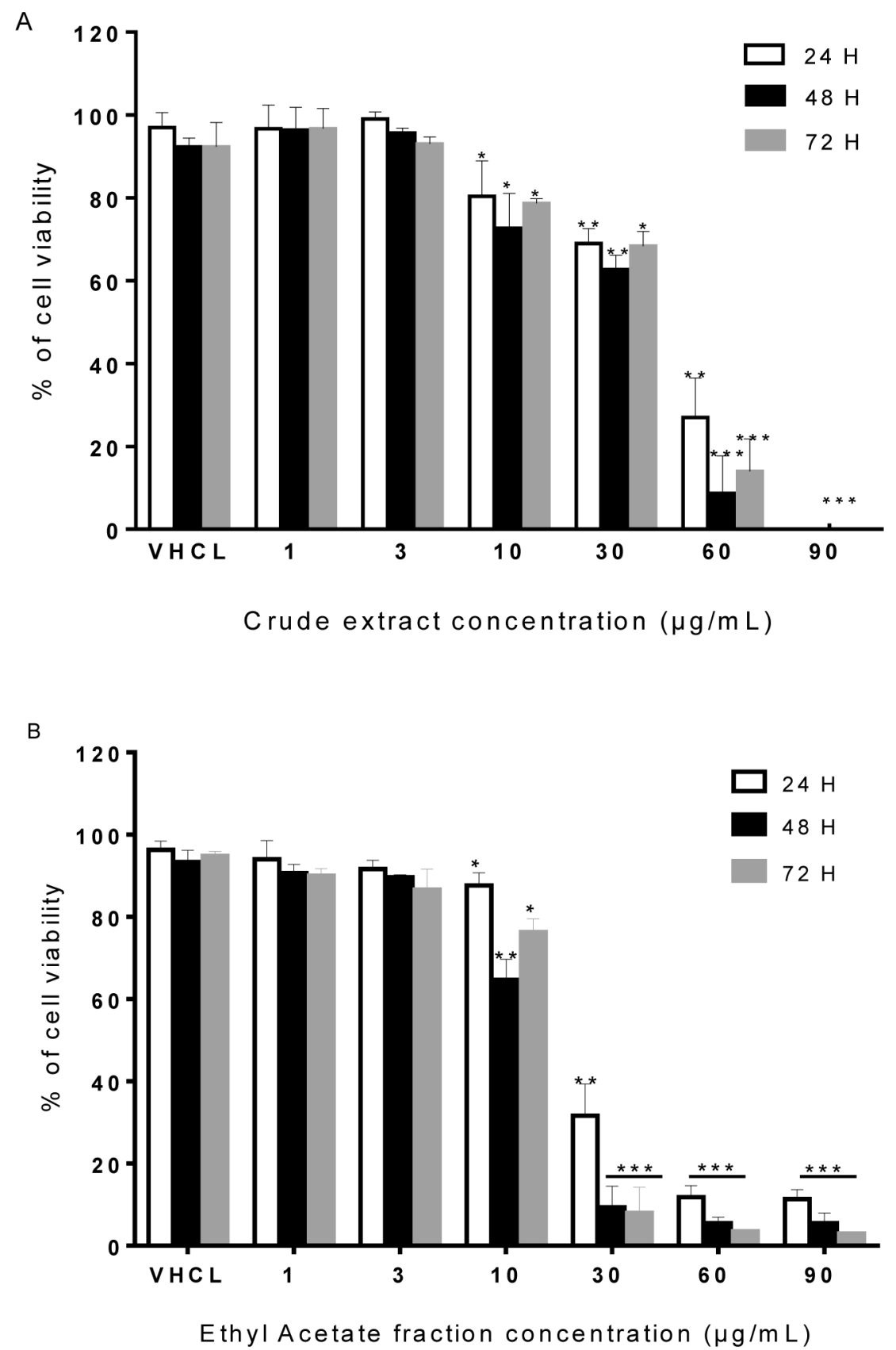

Figure 2 Cell viability of LHCN-M2 cells. (A) Cells were cultivated in the presence of CE $(1,3,10,30,60$ and $90 \mu \mathrm{g} / \mathrm{mL}$ ) for 24, 48 and $72 \mathrm{~h}$. (B) Cells were cultivated in the presence of EtOAc $(1,3,10,30,60$ and $90 \mu \mathrm{g} / \mathrm{mL}$ ) for 24,48 and $72 \mathrm{~h}$. The results were expressed as a percentage of treated cells normalized to untreated control cells. Vehicle (VHCL) treated cells were used as the negative control. Mean values (\% of control) with S.D. are indicated. This experiment was performed in duplicates and repeated three times. The significance $\left({ }^{*} p \leq 0.05,{ }^{* *} p \leq 0.01,{ }^{* * *} p<0.001\right)$ of cell viability in treated cells with respect to the untreated cells (CTRL). 

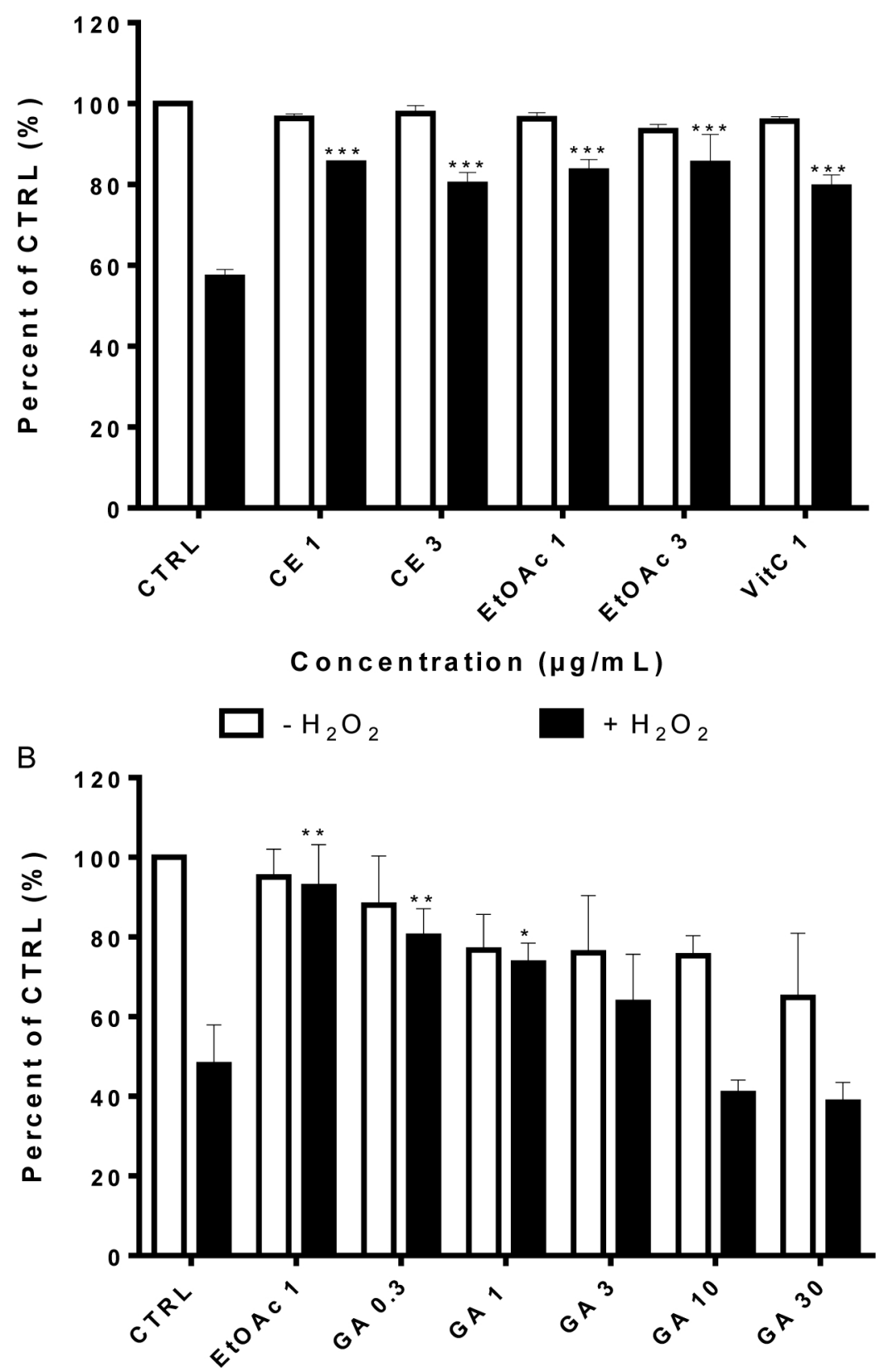

Concentration

$-\mathrm{H}_{2} \mathrm{O}_{2} \square+\mathrm{H}_{2} \mathrm{O}_{2}$

Figure 3 Viability of LHCN-M2 cells after pre-treatment with or without plant extracts for $48 \mathrm{~h}$ followed by exposure to hydrogen peroxide. Cells were cultivated in presence of (A) CE ( 1 and $3 \mu \mathrm{g} / \mathrm{mL}$ ), EtOAc ( 1 and $3 \mu \mathrm{g} / \mathrm{mL}$ ) and VitC $(1 \mu \mathrm{g} / \mathrm{mL})$ or (B) gallic acid $(1,3,10$ and $30 \mu \mathrm{M})$ for $48 \mathrm{~h}$ prior to stimulation with $75 \mu \mathrm{M} \mathrm{H}_{2} \mathrm{O}_{2}$ for $24 \mathrm{~h}$. The results were expressed as a percentage of treated cells normalized to untreated control cells. Untreated cells were used as the negative control; VitC was used as positive control. Mean values (\% of control) with S.D. are indicated. This experiment was performed in duplicate and repeated three times. The significance $\left({ }^{*} p<0.05,{ }^{* *} p<0.01,{ }^{* * *} p<0.001\right)$ of cell viability in treated cells/ $+\mathrm{H}_{2} \mathrm{O}_{2}$ with respect to the untreated cells $/-\mathrm{H}_{2} \mathrm{O}_{2}$. 

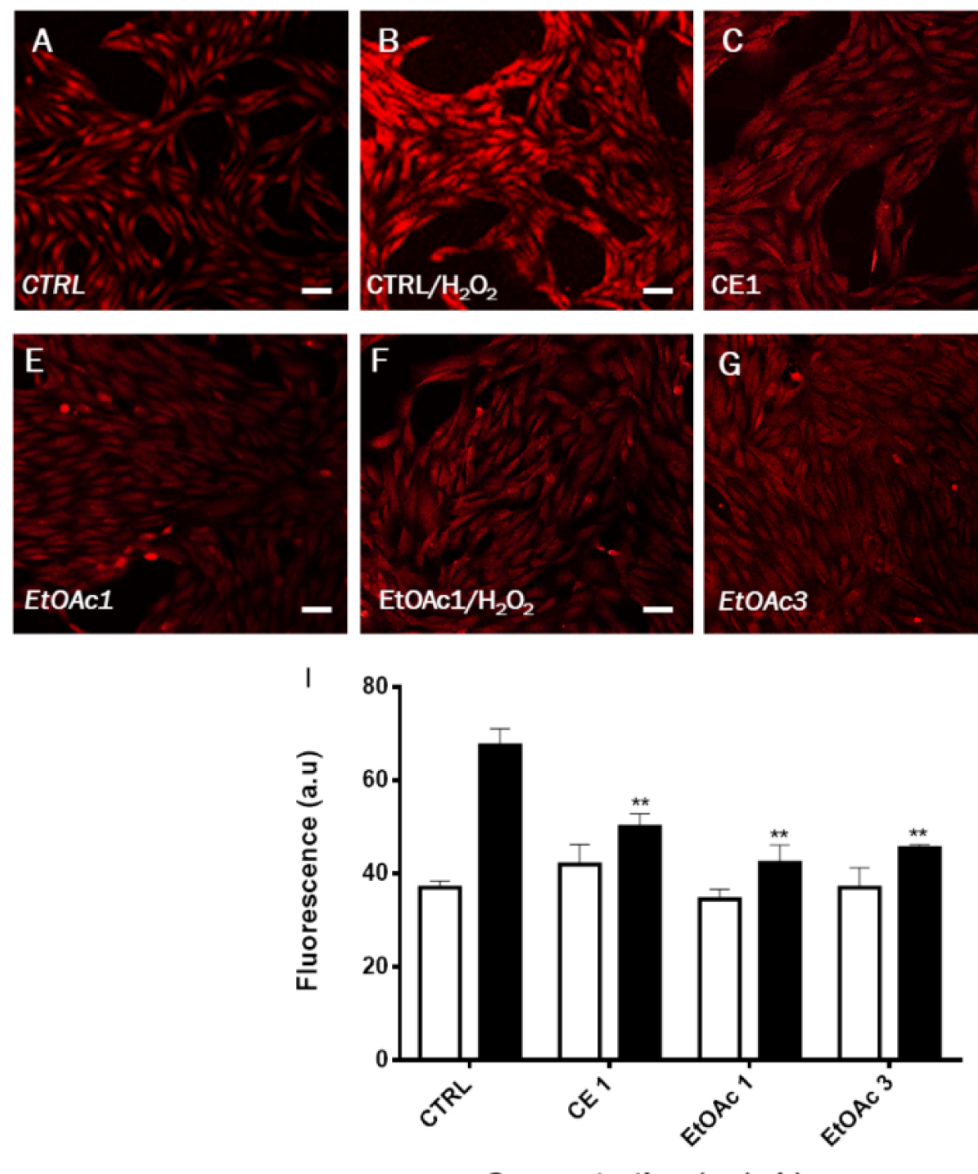

Concentration $(\mu \mathrm{g} / \mathrm{mL})$

$\square-\mathrm{H}_{2} \mathrm{O}_{2}$
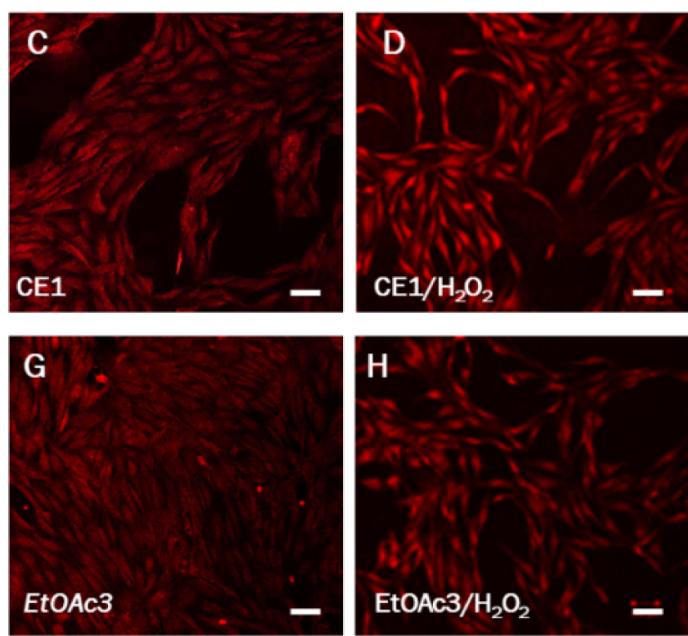

Figure 4 Assessment of ROS production in LHCN-M2 cells after pre-treated with sumac extracts and stimulated with $75 \mu \mathbf{M ~ H}_{2} \mathbf{O}_{2}$. (A-H), Representative DHE fluorescence staining of the oxidative stress. (I), Fluorescence was calculated and plotted on the graph for different concentrations of CE and EtOAc fractions of sumac using the ImageJ software. The significance $\left({ }^{* *} p \leq 0.01\right)$ of fluorescence in treated cells $/+\mathrm{H}_{2} \mathrm{O}_{2}$ with respect to the untreated cells $/-\mathrm{H}_{2} \mathrm{O}_{2}$. Scale bar $20 \mu \mathrm{m}$.

fraction, $1 \mu \mathrm{g} / \mathrm{mL}$ of CE or $1 \mu \mathrm{g} / \mathrm{mL}$ of VitC reduced the percentage of arrested cells to 4 to $8 \%$ (Fig. 5A). Both CE and the EtOAc fraction significantly reduced cell cycle arrest in LHCN-M2 cells subjected to oxidative stress. The low concentrations of sumac $\mathrm{CE}$ and EtOAc fraction did not affect LHCN-M2 cell cycle (Supplemental Information 1).

\section{The crude extract and the ethyl acetate fraction restore myoblast adhesion impaired by $\mathrm{H}_{2} \mathrm{O}_{2}$}

$\mathrm{H}_{2} \mathrm{O}_{2}$ is known to induce separation of cells from the substratum (Grossmann, 2002; Song et al., 2010); we examined the effects of $\mathrm{H}_{2} \mathrm{O}_{2}$ on myoblast adhesion in the presence of the sumac EtOAc fraction by using a quantitative adhesion assay. Cells were pre-treated for 2 days with CE extract at $1 \mu \mathrm{g} / \mathrm{mL}$ or EtOAc fraction at 1 and $3 \mu \mathrm{g} / \mathrm{mL}$ before being 


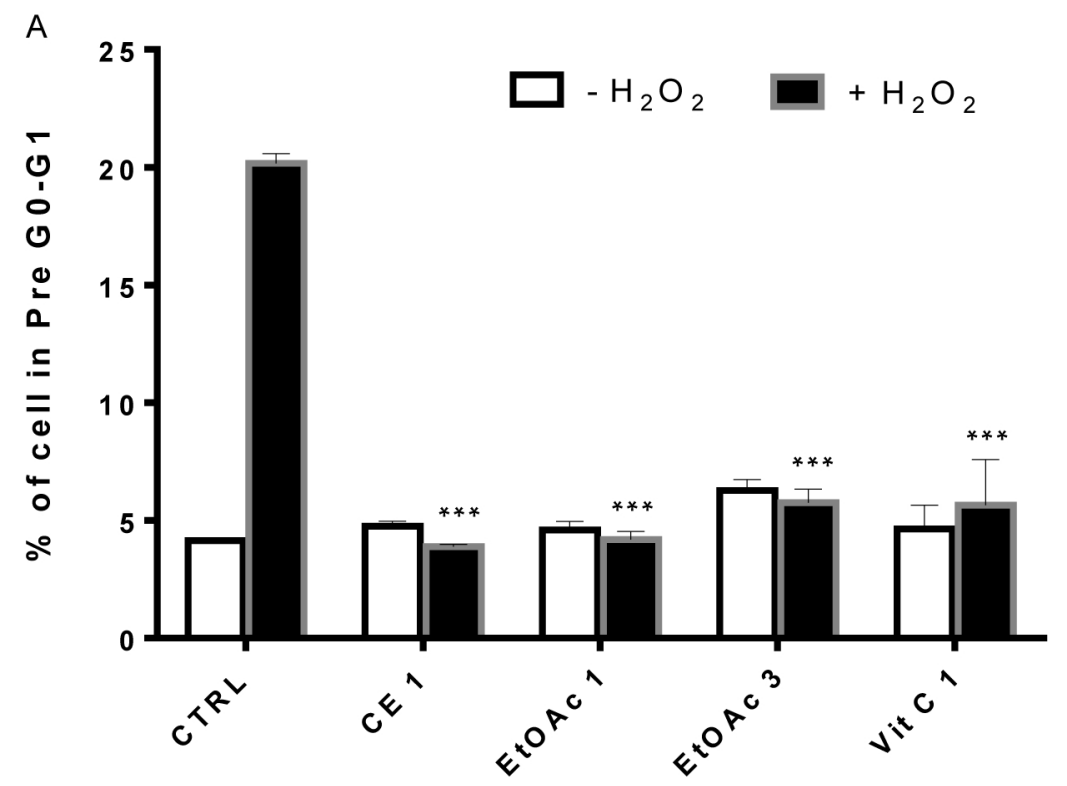

Concentration $(\mu g / m L)$

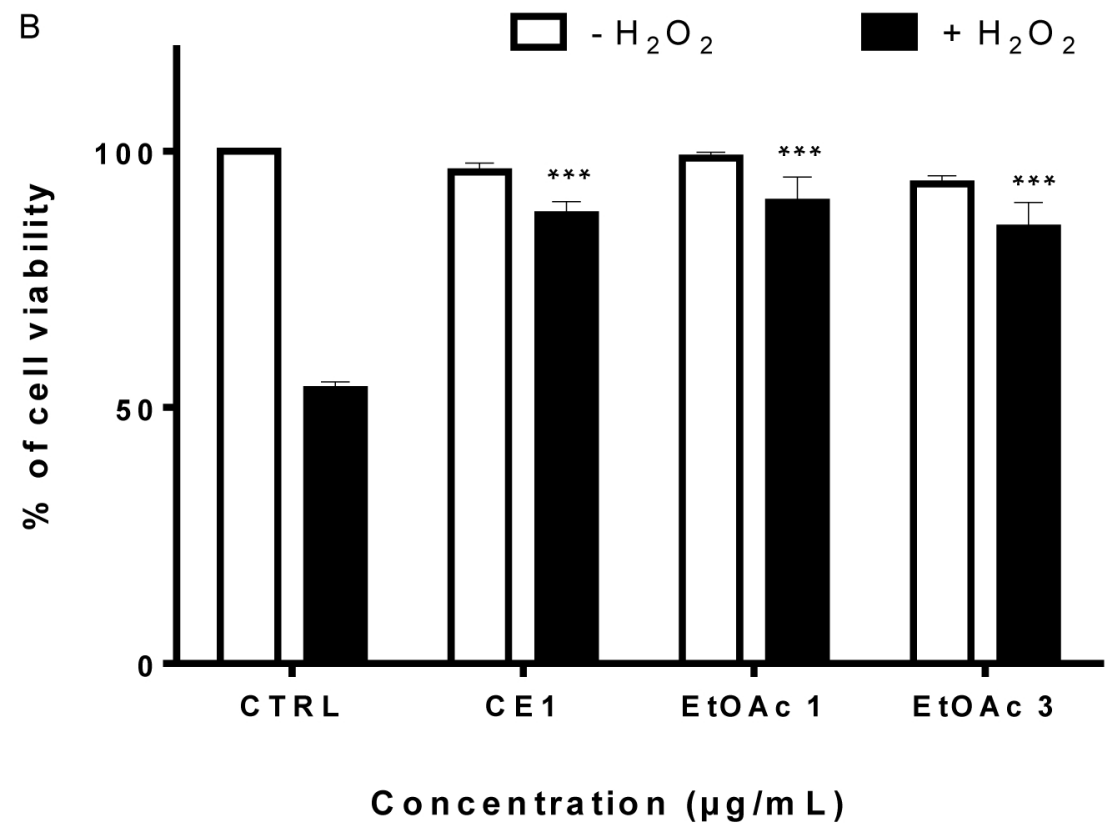

Figure 5 (A) Percentage of cells in pre G0/G1 of LHCN-M2 cells after pretreatment with sumac extracts and addition of $\mathrm{H}_{2} \mathrm{O}_{2}$. Cells were pre-treated with 1 and $3 \mu \mathrm{g} / \mathrm{mL}$ of the EtOAc fraction, $1 \mu \mathrm{g} / \mathrm{mL}$ of CE, $1 \mu \mathrm{g} / \mathrm{mL}$ of VitC for $48 \mathrm{~h}$, and incubated with $75 \mu \mathrm{M}$ of $\mathrm{H}_{2} \mathrm{O}_{2}$. The histogram shows the percentage of cells of the total population at pre G0-G1. Values are means of three independent experiments. The significance $\left.{ }^{* * *} p \leq 0.001\right)$ of cells in pre $\mathrm{G} 0 / \mathrm{Gl}$ in treated cells $/+\mathrm{H}_{2} \mathrm{O}_{2}$ with respect to untreated cells $/-\mathrm{H}_{2} \mathrm{O}_{2}$.

(B) EtOAc fraction of sumac restores human myoblast (continued on next page...) 
Figure 5 (...continued)

adhesion under oxidative stress conditions. Cells were pre-treated with 1 and $3 \mu \mathrm{g} / \mathrm{mL}$ of the EtOAc fraction, $1 \mu \mathrm{g} / \mathrm{mL}$ of CE, $1 \mu \mathrm{g} / \mathrm{mL}$ of VitC for XX hours, and incubated with $75 \mu \mathrm{M} \mathrm{of} \mathrm{H}_{2} \mathrm{O}_{2}$. The results of count were expressed as the percentage of treated cells normalized to untreated control cells. The untreated cells and the solvent treated cells were used as a negative control. Mean values ( $\%$ of control) with S.D. are indicated. This experiment was performed in duplicates and repeated three times. The significance $\left.{ }^{* * *} p<0.001\right)$ of cell viability in treated cells $/+\mathrm{H}_{2} \mathrm{O}_{2}$ with respect to untreated cells $/-\mathrm{H}_{2} \mathrm{O}_{2}$.

trypsinized, plated and immediately exposed to $75 \mu \mathrm{M}$ of $\mathrm{H}_{2} \mathrm{O}_{2}$ for 4 h. Non-adherent cells were then removed and adherent cells were collected and counted by the trypan blue exclusion test.

As shown in Fig. $5 \mathrm{~B}, \mathrm{H}_{2} \mathrm{O}_{2}$ leads to a highly significant decrease in myoblast adhesion $(p \leq 0.001)$ and induces non-adherence in $50 \%$ cells while pre-treatment of LHCN-M2 cells with EtOAc fractions $(1 \mu \mathrm{g} / \mathrm{mL}$ and $3 \mu \mathrm{g} / \mathrm{mL})$ significantly restored myoblasts adhesion to around $90 \%$. We have thus shown that pre-treatment of LHCN-M2 cells with CE extracts and EtOAc fraction prevented the deleterious effects of $\mathrm{H}_{2} \mathrm{O}_{2}$-induced oxidative stress in myoblasts and restored cells adhesion. Taking in consideration the low number of active molecules in the EtOAc fraction compared to the CE extract, the molecular study was conducted using only the low concentration of EtOAc fraction.

\section{SOD2 and catalase RNAs expression are activated by the ethyl acetate fraction}

We have previously shown that sumac extracts protected human myoblasts from $\mathrm{H}_{2} \mathrm{O}_{2}$ induced oxidative stress when pre-treated at least $48 \mathrm{~h}$ prior to $\mathrm{H}_{2} \mathrm{O}_{2}$ treatment. This may suggest an upregulation of genes encoding antioxidant enzymes. In order to identify genes that may mediate the anti-oxidant protective effect of sumac extracts, LHCN-M2 cells were treated for 2 days with either $1,3 \mu \mathrm{g} / \mathrm{mL}$ of the EtOAc fraction or Vitamin C. mRNA levels of GPx3, SOD2 and catalase antioxidant genes were determined by RT-qPCR. We have observed increased levels of SOD2 ( $\sim 1.8$ fold) in cells treated with $1 \mu \mathrm{g} / \mathrm{mL}$ of EtOAc fraction as compared to the untreated controls. Catalase level was also increased $(\sim 7.6$ fold) in all treated cells. The treatment induced a significant decrease in GPx3 expression (Fig. 6A). This result confirmed that SOD 2 and catalase might mediate the anti-cytotoxic effect of our extracts.

To investigate whether EtOAc fraction induces a change in the expression of the myoD gene family involved in muscle determination and differentiation, RT-qPCR was performed to evaluate the levels of myoD, myf5 and myogenin mRNAs in LHCN-M2 cells. In the case of myf5, a transcription factor engaged in muscle determination, a significant decreased was found in its expression in the case of both EtOAc fraction ( 1 and $3 \mu \mathrm{g} / \mathrm{mL}$ ) and VitC $(1 \mu \mathrm{g} / \mathrm{mL})$ (Fig. 6B). Expression of myogenin, a gene involved in muscle differentiation, was inhibited after EtOAc fraction ( 1 and $3 \mu \mathrm{g} / \mathrm{mL}$ ) and VitC treatment (Fig. 6C).

Thus, SOD2 and catalase might mediate the antioxidant effect of EtOAc fraction at low concentrations. EtOAc fraction and $\mathrm{VitC}$ might inhibit or delay muscle differentiation. Our results are in agreement with the published data that treatment of myoblasts with antioxidants inhibited muscle differentiation (Zakharova et al., 2016). 

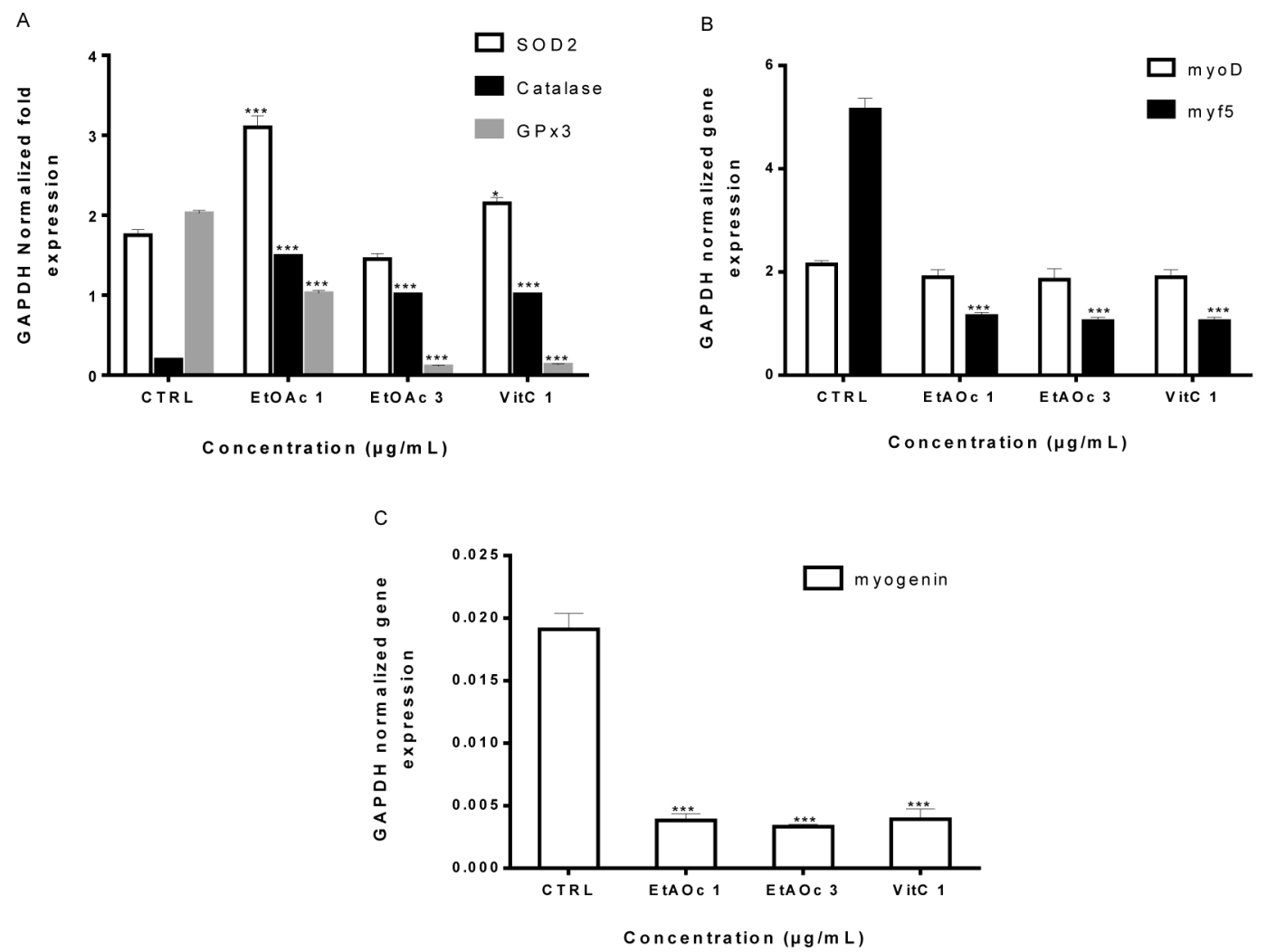

Figure 6 Expression of antioxidant genes GPx3, SOD, catalase and muscle determination and differentiation genes myoD, myf5 and myogenin in LHCN-M2 cells. The levels of Gpx3-SOD2 Catalase (A), myoD-myf5 (B) and myogenin (C). mRNA were analyzed using RT-qPCR $48 \mathrm{~h}$ after treatment with EtOAc fraction and VitC (A, B, C). Expression of GAPDH was used as an internal control to normalize the target gene levels. Experiments were performed twice. The significance $\left({ }^{*} p \leq 0.05,{ }^{* *} p \leq 0.01 \&{ }^{* * *} p<\right.$ 0.001) of gene expression in treated cells with respect to the untreated cells (CTRL).

\section{Low concentrations of sumac crude extract and the ethyl acetate fraction show no cytotoxic effect on zebrafish embryos}

We have next tested the cytotoxic effect of sumac extracts in vivo on zebrafish embryos. Lethality of zebrafish embryos treated with sumac $\mathrm{CE}$ and the EtOAc fraction was defined when embryos showed coagulation and no visual heartbeat. The viability of embryos after 24, 48, 72 and $96 \mathrm{~h}$ post-fertilization (hpf) of exposure to different concentrations of the extracts are shown in Fig. 7. At $24 \mathrm{hpf}$, normal morphological development was observed with the presence of tail, head, eye and embryonic movement. Approximately, $30 \%$ of eggs coagulated after treatment with CE extract $(60 \mu \mathrm{g} / \mathrm{mL})$ and EtOAc fraction $(60$ $\mu \mathrm{g} / \mathrm{mL}$ ). Embryos coagulation was concentration-dependent showing a high mortality at a concentration of $120 \mu \mathrm{g} / \mathrm{mL}$ for CE extract and EtOAc fraction (Figs. 7A-7C). Coagulation usually happens naturally in $4-5 \%$ of fertilized eggs.

No morphological abnormalities were seen at 48 hpf. Likewise, somite showed similar formation and number when comparing control to treated embryos with EtOAc fraction and CE. However, heart edema was observed at $96 \mathrm{hpf}$ in embryos treated with EtOAc 
A

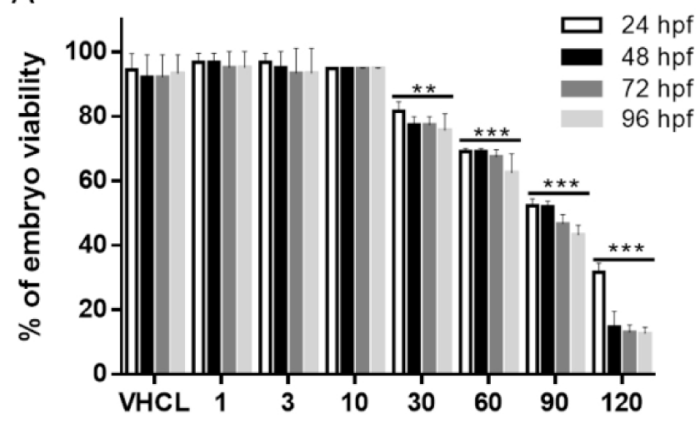

Crude extract concentrations $(\mu \mathrm{g} / \mathrm{mL})$
B

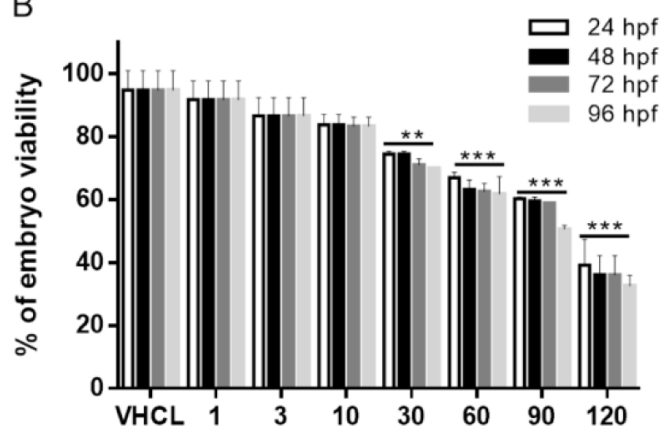

Ethyl acetate fraction concentrations $(\mu \mathrm{g} / \mathrm{mL})$

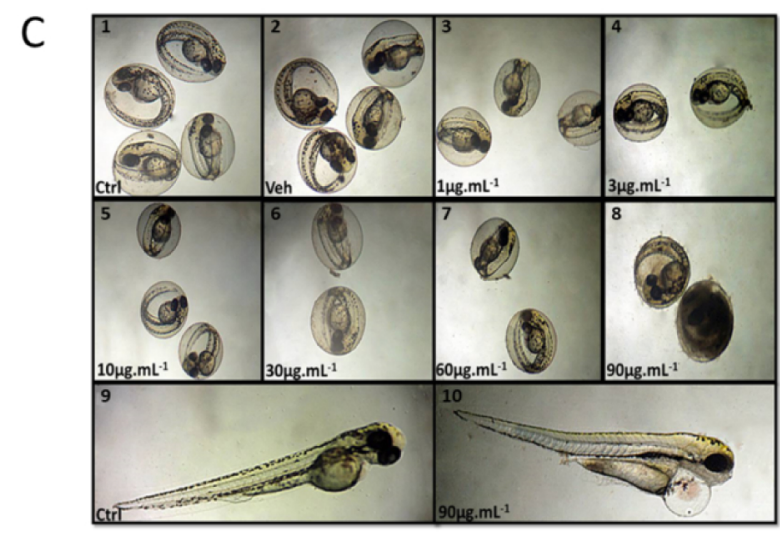

Figure 7 Viability of zebrafish embryos after exposure to the CE and EtOAc fraction at $24 \mathrm{~h}, 48 \mathrm{~h}, 72 \mathrm{~h}$ and $96 \mathrm{~h}$ post treatment. Effect of crude extract (A) and Ethyl acetate fraction (B) on zebrafish embryos, viability rate after treatment. Mean values (\% of control) are indicated. This experiment was performed in duplicates and repeated three times. ${ }^{* *} P<0.01,{ }^{* * *} P \leq 0.001$. (C) Morphological alteration of zebrafish embryos after exposure to sumac CE. (1-10): embryos at $72 \mathrm{hpf}$, 1 : Untreated, 2: DMSO, $3: 1 \mu \mathrm{g} / \mathrm{mL}, 4: 3$ $\mu \mathrm{g} / \mathrm{mL}, 5: 10 \mu \mathrm{g} / \mathrm{mL}, 6: 30 \mu \mathrm{g} / \mathrm{mL}, 7: 60 \mu \mathrm{g} / \mathrm{mL}, 8: 90 \mu \mathrm{g} / \mathrm{mL}$, Coagulation, 9: Untreated at $96 \mathrm{hpf}, 10: \mathrm{CE}$ $90 \mu \mathrm{g} / \mathrm{mL}$, the arrow indicates pericardial edema. Scale bars $500 \mu \mathrm{m}(1-8), 250 \mu \mathrm{m}(9-10)$.

fraction and CE at 90 and $120 \mu \mathrm{g} / \mathrm{mL}$. The latter observation may be due to an increase in the heart rate of the embryos (Figs. 7C-10). The treatment with CE and EtOAc fraction at $60 \mu \mathrm{g} / \mathrm{mL}$ or higher concentrations affected significantly the hatchability of the eggs

In order to determine whether sumac $\mathrm{CE}$ and EtOAc fraction have a protective effect on $\mathrm{H}_{2} \mathrm{O}_{2}$-treated embryos, survival assays were carried out. An $\mathrm{H}_{2} \mathrm{O}_{2}$ killing curve was generated after treatment of embryos with $2.10^{-3} \mathrm{~mol} / \mathrm{L}, 2.10^{-2} \mathrm{~mol} / \mathrm{L}$ and $2.10^{-1} \mathrm{~mol} / \mathrm{L}$ of $\mathrm{H}_{2} \mathrm{O}_{2}$ for $60 \mathrm{~min}$ at $24 \mathrm{hpf}$. The $\mathrm{H}_{2} \mathrm{O}_{2}$ concentration of $2.10^{-2} \mathrm{~mol} / \mathrm{L}$ was chosen for further studies; it corresponds to $\sim 50 \%$ survival of embryos

Embryos were pretreated at 4-6 hpf with different concentrations of CE, EtOAc fraction ( 1 and $3 \mu \mathrm{g} / \mathrm{mL}$ ) and $\mathrm{VitC}(100 \mu \mathrm{M})$ for $24 \mathrm{~h}$ and then exposed to $2.10^{-2} \mathrm{~mol} / \mathrm{L} \mathrm{H}_{2} \mathrm{O}_{2}$ or the $\mathrm{E} 3$ medium (control) at $24 \mathrm{hpf}$ for $2 \mathrm{~h}$. Treatment with the EtOAc fraction treatment at low concentrations ( 1 and $3 \mu \mathrm{g} / \mathrm{mL}$ ) increased the survival rate of $\mathrm{H}_{2} \mathrm{O}_{2}$-treated embryos 


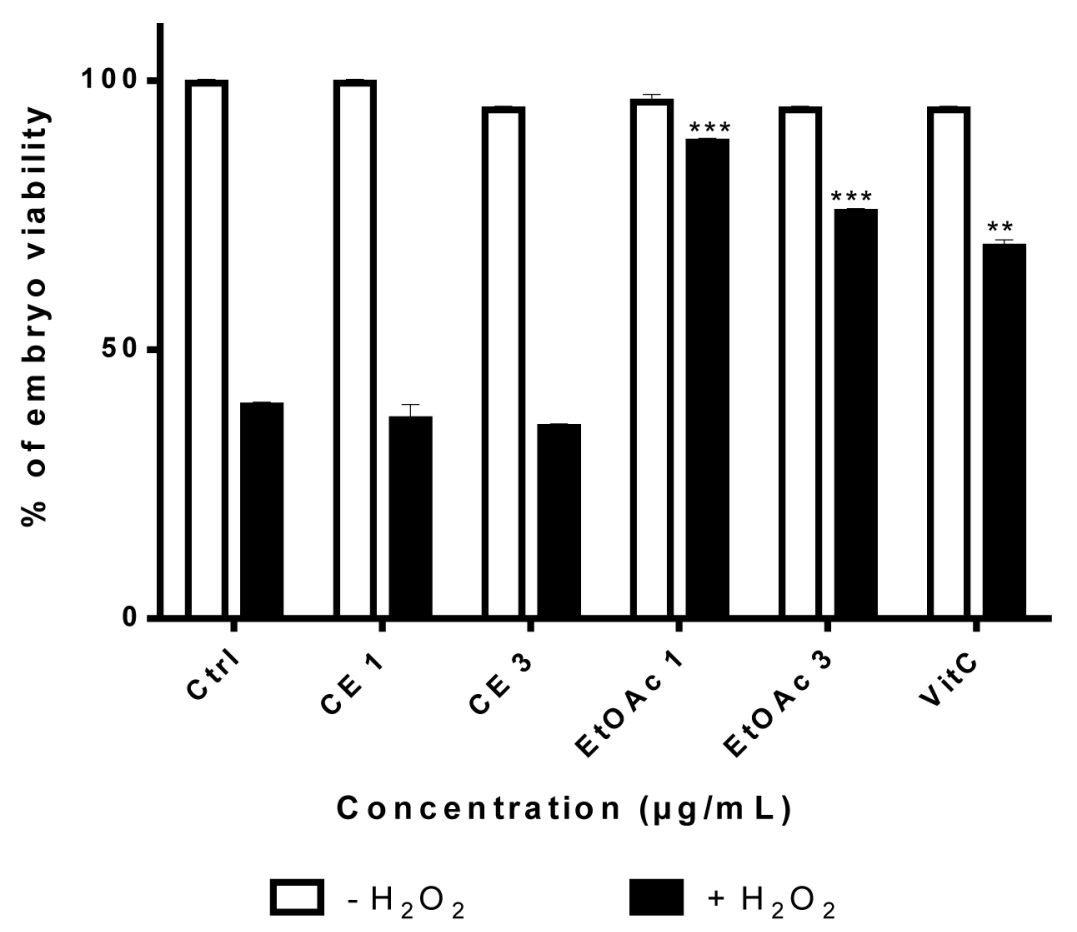

Figure 8 Viability rates of zebrafish embryos $24 \mathrm{~h}$ after treatment with different concentrations of sumac's CE ( 1 and $3 \mu \mathrm{g} / \mathrm{mL})$ extract, EtOAc fraction $(1$ and $3 \mu \mathrm{g} / \mathrm{mL}$ ) and VitC followed by exposure to $\mathrm{H}_{2} \mathrm{O}_{2}$ for $2 \mathrm{~h}$. The significance $\left({ }^{* *} p \leq 0.01 \&{ }^{* * *} p \leq 0.001\right)$ of embryos viability in treated cells $/+\mathrm{H}_{2} \mathrm{O}_{2}$ with respect to the untreated cells/ $-\mathrm{H}_{2} \mathrm{O}_{2}$.

relatively to untreated embryos (Fig. 8). Sumac CE failed to increase the viability of $\mathrm{H}_{2} \mathrm{O}_{2}$-treated embryos

\section{DISCUSSION}

Natural compounds from plants are an extremely important source of medicinal agents. A recent qualitative study of the phytochemical components from sumac fruit extract showed that this spice is an abundant source of bioactive molecules. It contains phenolic acids, flavonoids, iso-flavonoids, tannins, anthocyanins, etc. (Abu-Reidah et al., 2015). Here we have studied the antioxidant effect of Rhus coriaria extracts. First, we used DPPH scavenging and $\beta$-carotene bleaching assays to show that $\mathrm{CE}$ extract and the EtOAc fraction exhibit the greatest antioxidant activity compared to the positive controls (catechin and ascorbic acid). These results were consistent with others study in the literature. Indeed, Jamous et al. (2015) showed the antioxidant potential of Rhus coriaria methanolic extract using the DPPH scavenging test. A study of the antioxidant activity of water sumac extract compared to other plants extracts and showed that sumac possessed the highest antioxidant potential (Aliakbarlu, Mohammadi \& Khalili, 2014). Moreover, the aqueous and alcoholic extracts of $R$. coriaria were good scavengers for ROS and are a potential source of natural antioxidants for use in pharmaceutical or food industry (Al-Muwaly, Al-Flayeh \& Ali, 2013). Many other studies indicated that the antioxidant activity of sumac extracts might result from 
polyphenolic constituents, especially gallic acid and its derivatives (Chakraborty et al., 2009; Ferk et al., 2007; Gabr, El-Metwally \& Al-Ghadir, 2014). The antioxidative activity displayed by sumac extract and fractions are due to phenolic compounds and as shown by many studies, there was substantial relationship observed between total phenols and antioxidant activity (Kosar et al., 2007). All the phenols in CE extract and EtOAc fraction might act additively and even synergistically that subsequently increasing the antioxidant activity. Our results showed a protective antioxidant effect of gallic acid at low concentration; however, it is cytotoxic at high concentrations. It was mentioned that Gallic acid provokes DNA damage and suppresses DNA repair gene expression in human prostate cancer PC-3 cells (Liu et al., 2013). This cytotoxic activity of gallic acid might explain why the sumac cytotoxicity increases at high concentrations. Consequently, the crude extract or the EtOAc fraction can be utilized as an effective natural antioxidant source.

Here we have identified a new function for Rhus coriaria. The ethyl acetate fraction of $R$. coriaria has the ability to protect muscle satellite cells from induced oxidative stress. Furthermore, we have shown for the first time that sumac extracts had the same protective effect in vivo on zebrafish embryos. Indeed, EtOAc fraction improved survival and protected myoblasts and zebrafish embryos from oxidative stress. This fraction significantly reduced cell cycle arrest in myoblasts subjected to oxidative stress. It also protected human myoblasts from $\mathrm{H}_{2} \mathrm{O}_{2}$-induced oxidative stress by increasing the expression of the SOD2 and catalase. Moreover, it might delay muscle differentiation by decreasing myogenin expression.

Riederer et al. (2012) reported that, 3 days after transplantation, myoblasts undergo differentiation, hence limiting their ability to proliferate. Our results indicate that sumac extract decreases myogenic markers' expression, which may result in delayed differentiation. This supports a function for sumac extract to enhance cell survival and proliferation concomitant with a delay in differentiation during this critical time window of 3 days post-implantation, allowing more efficient skeletal muscle regeneration.

The role of oxidative stress in muscle pathology (Canton, Menazza \& Lisa, 2014; Terrill et al., 2013) was implicated early by the observation that muscles from Duchenne Muscular Dystrophy patients contain a higher level of thiobarbituric acid reactive products, which was indicative of lipid peroxidation brought about by oxidative stress (Kar \& Pearson, 1979). Moreover, muscle cells from FSHD patients show increased susceptibility to oxidative stress, augmented lipofuscin inclusions, elevated expression of antioxidant enzymes, dysfunctional mitochondria (Turki et al., 2012) and high levels of DNA damage (Dmitriev et al., 2016).

Myoblast transplantation represents a viable approach for the treatment of myopathies associated with fiber necrosis and muscle weakness (Gussoni, Blau \& Kunkel, 1997). Transplanted myoblasts can fuse with endogenous muscle fibers to form myotubes (Partridge et al., 1989). However, cell-based therapy for skeletal muscles degenerative diseases is still disappointing. There is evidence that oxidative stress, which is presumably derived from damage resulting from intramuscular implantation, might cause rapid cell death and hence poor outcome. The enhancement of cell survival by protecting from oxidative stress highlights the need to find new and potent natural antioxidants to improve cell- based therapy for muscle diseases and to delay muscle aging. 
Mature skeletal muscle cells, as well as myogenic stem and progenitor cells, elaborate sophisticated enzymatic antioxidant systems; this renders them extremely flexible in response to changes in redox potential (Beckendorf \& Linke, 2015; Powers, Talbert \& Adhihetty, 2011). The primary antioxidant enzymes in muscle cells include superoxide dismutase, glutathione peroxidase, and catalase. Dystrophic muscles exhibit enhanced catalase, SOD, and glutathione reductase activity, which is reflective of oxidative stress (Candan \& Sökmen, 2004). A previous study showed that GPx3 plays a major role in human myoblast viability and mediates the anti-cytotoxic effect of RA (El Haddad et al., 2012). In our study, the levels of SOD2 and catalase were increased in cells treated with low concentrations of the EtOAc fraction, whereas this treatment induced a significant decrease in the expression of GPx3 mRNA. This result shows that SOD and catalase are implicated in the protective antioxidant effect of the EtOAc fraction.

This study is also the first complete assessment of the toxicity and antioxidant activity of sumac fruit extracts on zebrafish embryos. Zebrafish are widely used for in vitro assays in drug/pharmaceutical research (Alestrom, Holter \& Nourizadeh-Lillabadi, 2006). The CE and the EtOAc fraction were screened for their effects on the development of zebrafish embryos. None of the extracts induced abnormal development of embryos at low concentrations. However, high concentrations were associated with developmental abnormalities in a dose-dependent manner. The embryos treated with high doses of sumac extracts showed cardiac edema with the enlarged cardiac chamber (cardiac hypertrophy). Furthermore, the embryo pretreatment with a low concentration of the EtOAc fraction protected zebrafish from $\mathrm{H}_{2} \mathrm{O}_{2}$-induced oxidative stress.

\section{CONCLUSION}

Normal muscle cells and myoblast are both sensitive to oxidative stress. Hence, a comprehensive therapeutic approach to muscle atrophy should take into account the relative contribution of oxidative stress. Natural antioxidant treatment represents a promising strategy in the treatment of muscular pathologies by preventing oxidative injury and potentially delay disease progression.

Here we have found that crude and ethyl acetate fraction inhibited or slow down the progress of skeletal muscle atrophy by decreasing oxidative stress, thus playing a major role in the modulation of cells aging process. In myoblasts, these extracts can increase the viability of implanted skeletal muscle precursor. The current results are also encouraging for screening the effect of other medicinal plants on zebrafish embryos for drug discovery, biotechnological and medical applications. Therefore, further studies are required to gain more insights into the protective mechanisms of sumac extracts.

\section{Abbreviations}

$\begin{array}{ll}\text { Aq } & \text { Aqueous } \\ \text { CE } & \text { Crude extract } \\ \text { DPPH } & \text { free radical scavenging activity } \\ \text { DHE } & \text { Dihydroethidium } \\ \text { EtOAc } & \text { Ethyl acetate }\end{array}$




$\begin{array}{ll}\text { Hex } & \text { Hexane } \\ \mathbf{H}_{2} \mathbf{O}_{2} & \text { Hydrogen peroxide } \\ \mathbf{h p f} & \text { Hour post fertilization } \\ \mathbf{I C}_{50} & \text { Inhibition concentration } \\ \text { MD } & \text { Muscular disptrophies } \\ \text { ROS } & \text { Reactive oxygene species } \\ \text { SA } & \text { scavenging activity } \\ \text { VitC } & \text { Vitamin C }\end{array}$

\section{ADDITIONAL INFORMATION AND DECLARATIONS}

\section{Funding}

The study was funded by the National Council for Scientific Research (CNRS)-Lebanon, the Lebanese University- Lebanon, the Doctoral School of Sciences and Technology (EDST)-Lebanon, Lebanese University, and Edde Association-Lebanon. The funders had no role in study design, data collection and analysis, decision to publish, or preparation of the manuscript.

\section{Grant Disclosures}

The following grant information was disclosed by the authors:

National Council for Scientific Research (CNRS)-Lebanon.

The Lebanese University- Lebanon.

Doctoral School of Sciences and Technology (EDST)-Lebanon, Lebanese University.

Edde Association-Lebanon.

\section{Competing Interests}

The authors declare there are no competing interests.

\section{Author Contributions}

- Fadia Najjar and Aline Hamade conceived and designed the experiments, analyzed the data, contributed reagents/materials/analysis tools, wrote the paper, prepared figures and/or tables, reviewed drafts of the paper.

- Francine Rizk conceived and designed the experiments, analyzed the data, reviewed drafts of the paper.

- Gilles Carnac conceived and designed the experiments, performed the experiments, contributed reagents/materials/analysis tools, reviewed drafts of the paper.

- Rim Nassar performed the experiments, reviewed drafts of the paper.

- Sara Jabak and Yara Bou Saada performed the experiments, prepared figures and/or tables, reviewed drafts of the paper.

- Anatoly Petrovich Sobolev performed the experiments, analyzed the data, contributed reagents/materials/analysis tools, reviewed drafts of the paper.

- Marwan El Sabban conceived and designed the experiments, analyzed the data, contributed reagents/materials/analysis tools, reviewed drafts of the paper. 


\section{Animal Ethics}

The following information was supplied relating to ethical approvals (i.e., approving body and any reference numbers):

The ethical panel of the department of Life \& Earth Sciences of the Lebanese UniversityFaculty of Sciences/Fanar fully approved this research.

\section{Field Study Permissions}

The following information was supplied relating to field study approvals (i.e., approving body and any reference numbers):

As we already mentioned in the Material and Methods section, the fresh fruit from Rhus coriaria L. plant was collected from South Lebanon. No field permit was required because the fresh fruits were collected from a private field (that the corresponding author owns). Fresh fruit was only collected from the field and all experimental procedures were done in the laboratory.

\section{REFERENCES}

Abu-Reidah IM, Ali-Shtayeh MS, Jamous RM, Arráez-Román D, Segura-Carretero A. 2015. HPLC-DAD-ESI-MS/MS screening of bioactive components from Rhus coriaria L. (Sumac) fruits. Food Chemistry 166:179-191

DOI 10.1016/j.foodchem.2014.06.011.

Al-Muwaly KY, Al-Flayeh KA, Ali A. 2013. Antioxidant and free radical scavenging effects of Iraqi sumac (Rhus coriaria L). Baghdad Science Journal 10:921-933.

Alestrom P, Holter JL, Nourizadeh-Lillabadi R. 2006. Zebrafish in functional genomics and aquatic biomedicine. Trends in Biotechnology 24:15-21

DOI 10.1016/j.tibtech.2005.11.004.

Ali-Shtayeh MS, Al-Assali AA, Jamous RM. 2013. Antimicrobial activity of Palestinian medicinal plants against acne-inducing bacteria. African Journal of Microbiology Research 7:2560-2573 DOI 10.5897/AJMR12.1875.

Aliakbarlu J, Mohammadi S, Khalili S. 2014. A study on antioxidant potency and antibacterial activity of water extracts of some spices widely consumed in Iranian diet. Journal of Food Biochemistry 38:159-166 DOI 10.1111/jfbc.12034.

Auezova L, Najjar F, Selivanova O, Moussa EH, Assaf MD. 2013. Antioxidant activity of brown alga Saccharina bongardiana from Kamchatka (Pacific coast of Russia). A methodological approach. Journal of Applied Phycology 25:1189-1196 
Beckendorf L, Linke WA. 2015. Emerging importance of oxidative stress in regulating striated muscle elasticity. Journal of Muscle Research and Cell Motility 36:25-36 DOI 10.1007/s10974-014-9392-y.

Brand-Williams W, Cuvelier M-E, Berset C. 1995. Use of a free radical method to evaluate antioxidant activity. LWT-Food Science and Technology 28:25-30 DOI 10.1016/S0023-6438(95)80008-5.

Bross R, Storer T, Bhasin S. 1999. Aging and Muscle Loss. Trends in Endocrinology and Metabolism 10:194-198 DOI 10.1016/S1043-2760(98)00143-X.

Candan F, Sökmen A. 2004. Effects of Rhus coriaria L.(Anacardiaceae) on lipid peroxidation and free radical scavenging activity. Phytotherapy Research 18:84-86 DOI 10.1002/ptr.1228.

Canton M, Menazza S, Di Lisa F. 2014. Oxidative stress in muscular dystrophy: from generic evidence to specific sources and targets. Journal of Muscle Research and Cell Motility 35:23-36 DOI 10.1007/s10974-014-9380-2.

Chakraborty A, Ferk F, Simić T, Brantner A, Dušinská M, Kundi M, Hoelzl C, Nersesyan A, Knasmüller S. 2009. DNA-protective effects of sumach (Rhus coriaria L.), a common spice: results of human and animal studies. Mutation Research/Fundamental and Molecular Mechanisms of Mutagenesis 661:10-17 DOI 10.1016/j.mrfmmm.2008.10.009.

Clanton TL, Zuo L, Klawitter P. 1999. Oxidants and skeletal muscle function: physiologic and pathophysiologic implications. Proceedings of the Society for Experimental Biology and Medicine 222:253-262 DOI 10.1046/j.1525-1373.1999.d01-142.x.

Collins CA, Olsen I, Zammit PS, Heslop L, Petrie A, Partridge TA, Morgan JE. 2005. Stem cell function, self-renewal, and behavioral heterogeneity of cells from the adult muscle satellite cell niche. Cell 122:289-301 DOI 10.1016/j.cell.2005.05.010.

Dmitriev P, Bou Saada Y, Dib C, Ansseau E, Barat A, Hamade A, Dessen P, Robert T, Lazar V, Louzada RAN, Dupuy C, Zakharova V, Carnac G, Lipinski M, Vassetzky YS. 2016. DUX4-induced constitutive DNA damage and oxidative stress contribute to aberrant differentiation of myoblasts from FSHD patients. Free Radical Biology and Medicine 99:244-258 DOI 10.1016/j.freeradbiomed.2016.08.007.

Dolara P, Bigagli E, Collins A. 2012. Antioxidant vitamins and mineral supplementation, life span expansion and cancer incidence: a critical commentary. European Journal Nutrition 51:769-781 DOI 10.1007/s00394-012-0389-2.

Ekker M, Akimenkko MA. 1991. Le poisson zèbre (danio rerio), un modèle en biologie du développement. Médecine/Sciences 7(6):553-560.

El Haddad M, Jean E, Turki A, Hugon G, Vernus B, Bonnieu A, Passerieux E, Hamade A, Mercier J, Laoudj-Chenivesse D, Carnac G. 2012. Glutathione peroxidase 3, a new retinoid target gene, is crucial for human skeletal muscle precursor cell survival. Journal of Cell Science 125:6147-6156 DOI 10.1242/jcs.115220.

Emery AE. 2002. The muscular dystrophies. Lancet 359:687-695

DOI 10.1016/S0140-6736(02)07815-7. 
Ferk F, Chakraborty A, Simic T, Kundi M, Knasmüller S. 2007. Antioxidant and free radical scavenging activities of sumac (Rhus coriaria) and identification of gallic acid as its active principle. BMC Pharmacology 7:A71 DOI 10.1186/1471-2210-7-S2-A71.

Flanigan KM. 2012. The muscular dystrophies. Seminars in Neurology 32:255-263 DOI 10.1055/s-0032-1329199.

Frontera WR, Ochala J. 2015. Skeletal muscle: a brief review of structure and function. Calcified Tissue International 96:183-195 DOI 10.1007/s00223-014-9915-y.

Gabr SA, El-Metwally MM, Al-Ghadir AH. 2014. Antioxidant and antibacterial active constituents of Rhus coriaria. Biotechnology 13:37 DOI 10.3923/biotech.2014.37.45.

Gems D, Doonan R. 2009. Antioxidant defense and aging in C. legans: is the oxidative damage theory of aging wrong? Cell Cycle 8:1681-1687 DOI 10.4161/cc.8.11.8595.

Grossmann J. 2002. Molecular mechanisms of "detachment-induced apoptosisAnoikis". Apoptosis 7:247-260 DOI 10.1023/A:1015312119693.

Gussoni E, Blau HM, Kunkel LM. 1997. The fate of individual myoblasts after transplantation into muscles of DMD patients. Nature Medicine 3:970-977 DOI 10.1038/nm0997-970.

Halliwell B, Gutteridge JMC. 2015. Free radicals in biology and medicine. Fifth Edition. Oxford: Oxford University Press.

Harman D. 1956. Aging: a theory based on free radical and radiation chemistry. Journals of Gerontology Series A: Biological Sciences and Medical Sciences 11:298-300.

Hekimi S, Lapointe J, Wen Y. 2011. Taking a "good" look at free radicals in the aging process. Trends in Cell Biology 21:569-576 DOI 10.1016/j.tcb.2011.06.008.

Hong CC. 2009. Large-scale small-molecule screen using zebrafish embryos. Methods in Molecular Biology 486:43-55 DOI 10.1007/978-1-60327-545-3_4.

Howe K, Clark MD, Torroja CF, Torrance J, Berthelot C, Muffato M, Collins JE, Humphray S, McLaren K, Matthews L, McLaren S, Sealy I, Caccamo M, Churcher C, Scott C, Barrett JC, Koch R, Rauch GJ, White S, Chow W, Kilian B, Quintais LT, Guerra-Assuncao JA, Zhou Y, Gu Y, Yen J, Vogel JH, Eyre T, Redmond S, Banerjee R, Chi J, Fu B, Langley E, Maguire SF, Laird GK, Lloyd D, Kenyon E, Donaldson S, Sehra H, Almeida-King J, Loveland J, Trevanion S, Jones M, Quail M, Willey D, Hunt A, Burton J, Sims S, McLay K, Plumb B, Davis J, Clee C, Oliver K, Clark R, Riddle C, Elliot D, Threadgold G, Harden G, Ware D, Begum S, Mortimore B, Kerry G, Heath P, Phillimore B, Tracey A, Corby N, Dunn M, Johnson C, Wood J, Clark S, Pelan S, Griffiths G, Smith M, Glithero R, Howden P, Barker N, Lloyd C, Stevens C, Harley J, Holt K, Panagiotidis G, Lovell J, Beasley H, Henderson C, Gordon D, Auger K, Wright D, Collins J, Raisen C, Dyer L, Leung K, Robertson L, Ambridge K, Leongamornlert D, McGuire S, Gilderthorp R, Griffiths C, Manthravadi D, Nichol S, Barker G, Whitehead S, Kay M, Brown J, Murnane C, Gray E, Humphries M, Sycamore N, Barker D, Saunders D, Wallis J, Babbage A, Hammond S, Mashreghi-Mohammadi M, Barr L, Martin S, Wray P, Ellington A, Matthews N, Ellwood M, Woodmansey R, Clark G, Cooper J, Tromans A, Grafham D, Skuce C, Pandian R, Andrews R, Harrison E, Kimberley A, Garnett J, Fosker N, Hall R, Garner P, Kelly D, Bird C, Palmer S, Gehring I, Berger A, Dooley 
CM, Ersan-Urun Z, Eser C, Geiger H, Geisler M, Karotki L, Kirn A, Konantz J, Konantz M, Oberlander M, Rudolph-Geiger S, Teucke M, Lanz C, Raddatz G, Osoegawa K, Zhu B, Rapp A, Widaa S, Langford C, Yang F, Schuster SC, Carter NP, Harrow J, Ning Z, Herrero J, Searle SM, Enright A, Geisler R, Plasterk RH, Lee C, Westerfield M, De Jong PJ, Zon LI, Postlethwait JH, Nusslein-Volhard C, Hubbard TJ, Roest Crollius H, Rogers J, Stemple DL. 2013. The zebrafish reference genome sequence and its relationship to the human genome. Nature 496:498-503 DOI 10.1038/nature12111.

Jamous R, Zaitoun S, Husein A, Qasem I, Ali-Shtayeh M. 2015. Screening for biological activities of medicinal plants used in traditional arabic palestinian herbal medicine. European Journal of Medicinal Plants 9:1-13 DOI 10.9734/EJMP/2015/17429.

Kar NC, Pearson CM. 1979. Catalase, superoxide dismutase, glutathione reductase and thiobarbituric acid-reactive products in normal and dystrophic human muscle. Clinica Chimica Acta 94:277-280 DOI 10.1016/0009-8981(79)90076-7.

Kimmel CB, Ballard WW, Kimmel SR, Ullmann B, Schilling TF. 1995. Stages of embryonic development of the zebrafish. Developmental Dynamics 203:253-310 DOI 10.1002/aja.1002030302.

Koleva II, Van Beek TA, Linssen JP, De Groot A, Evstatieva LN. 2002. Screening of plant extracts for antioxidant activity: a comparative study on three testing methods. Phytochemical Analysis 13:8-17 DOI 10.1002/pca.611.

Kosar M, Bozan B, Temelli F, Baser K. 2007. Antioxidant activity and phenolic composition of sumac (Rhus coriaria L.) extracts. Food Chemistry 103:952-959 DOI 10.1016/j.foodchem.2006.09.049.

Kossah R, Nsabimana C, Zhang H, Chen W. 2013. Evaluation of antimicrobial and antioxidant activities of Syrian sumac fruit extract. Journal of Natural Products 6:96-102.

Kossah R, Nsabimana C, Zhao J, Chen H, Tian F, Zhang H, Chen W. 2009. Comparative study on the chemical composition of Syrian sumac (Rhus coriaria L.) and Chinese sumac (Rhus typhina L.) fruits. Pakistan Journal of Nutrition 8:1570-1574 DOI 10.3923/pjn.2009.1570.1574.

Liu KC, Ho HC, Huang AC, Ji BC, Lin HY, Chueh FS, Yang JS, Lu CC, Chiang JH, Meng M, Chung JG. 2013. Gallic acid provokes DNA damage and suppresses DNA repair gene expression in human prostate cancer PC-3 cells. Environmental Toxicology 28:579-587 DOI 10.1002/tox.20752.

MacRae CA, Peterson RT. 2003. Zebrafish-based small molecule discovery. Chemistry and Biology 10:901-908 DOI 10.1016/j.chembiol.2003.10.003.

Moylan JS, Reid MB. 2007. Oxidative stress, chronic disease, and muscle wasting. Muscle and Nerve 35:411-429 DOI 10.1002/mus.20743.

Onkar S, Mohammed A, Nida A. 2011. New antifungal aromatic compounds from the seeds of Rhus coriaria L. International Research Journal of Pharmacy 2:188-194.

Organisation for Economic Co-operation and Development (OECD). 1992. Guidelines for testing of chemicals no. 210. Fish, early-life stage toxicity test. Paris: OECD. 
Özcan M, Haciseferogullari H. 2004. A condiment [sumac (Rhus coriaria L.) fruits]: some physicochemical properties. Bulgarian Journal of Plant Physiology 30:74-84.

Parng C, Seng WL, Semino C, McGrath P. 2002. Zebrafish: a preclinical model for drug screening. Assay and Drug Development Technologies 1:41-48

DOI 10.1089/154065802761001293.

Partridge TA, Morgan JE, Coulton GR, Hoffman EP, Kunkel LM. 1989. Conversion of mdx myofibres from dystrophin-negative to -positive by injection of normal myoblasts. Nature 337:176-179 DOI 10.1038/337176a0.

Peault B, Rudnicki M, Torrente Y, Cossu G, Tremblay JP, Partridge T, Gussoni E, Kunkel LM, Huard J. 2007. Stem and progenitor cells in skeletal muscle development, maintenance, and therapy. Molecular Therapy 15:867-877 DOI 10.1038/mt.si.6300145.

Powers SK, Jackson MJ. 2008. Exercise-induced oxidative stress: cellular mechanisms and impact on muscle force production. Physiological Reviews 88:1243-1276 DOI 10.1152/physrev.00031.2007.

Powers SK, Talbert EE, Adhihetty PJ. 2011. Reactive oxygen and nitrogen species as intracellular signals in skeletal muscle. Journal de Physiologie 589:2129-2138 DOI 10.1113/jphysiol.2010.201327.

Rayne S, Mazza G. 2007. Biological activities of extracts from sumac (Rhus spp.): a review. Plant Foods for Human Nutrition 62:165-175 DOI 10.1007/s11130-007-0058-4.

Reid MB, Shoji T, Moody MR, Entman ML. 1992. Reactive oxygen in skeletal muscle. II. Extracellular release of free radicals. Journal of Applied Physiology 73:1805-1809.

Riederer I, Negroni E, Bencze M, Wolff A, Aamiri A, Di Santo JP, Silva-Barbosa SD, Butler-Browne G, Savino W, Mouly V. 2012. Slowing down differentiation of engrafted human myoblasts into immunodeficient mice correlates with increased proliferation and migration. Molecular Therapy 20:146-154 DOI 10.1038/mt.2011.193.

Sacco A, Doyonnas R, Kraft P, Vitorovic S, Blau HM. 2008. Self-renewal and expansion of single transplanted muscle stem cells. Nature 456:502-506 DOI 10.1038/nature07384.

Shefer G, Van de Mark DP, Richardson JB, Yablonka-Reuveni Z. 2006. Satellite-cell pool size does matter: defining the myogenic potency of aging skeletal muscle. Developmental Biology 294:50-66 DOI 10.1016/j.ydbio.2006.02.022.

Sies H. 2007. Biological redox systems and oxidative stress. Cellular and Molecular Life Science 64:2181-2188 DOI 10.1007/s00018-007-7230-8.

Sies H, Cadenas E. 1985. Oxidative stress: damage to intact cells and organs. Philosophical Transactions of the Royal Society of London B Biological Sciences 311:617-631 DOI 10.1098/rstb.1985.0168.

Sobolev AP, Carradori S, Capitani D, Vista S, Trella A, Marini F, Mannina L. 2014. Saffron samples of different origin: an NMR study of microwave-assisted extracts. Foods 3:403-419 DOI 10.3390/foods3030403.

Song H, Cha MJ, Song BW, Kim IK, Chang W, Lim S, Choi EJ, Ham O, Lee SY, Chung N, Jang Y, Hwang KC. 2010. Reactive oxygen species inhibit adhesion of 
mesenchymal stem cells implanted into ischemic myocardium via interference of focal adhesion complex. Stem Cells 28:555-563 DOI 10.1002/stem.302.

Sylla T, Pouysegu L, Da Costa G, Deffieux D, Monti JP, Quideau S. 2015. Gallotannins and tannic acid: first chemical syntheses and in vitro inhibitory activity on alzheimer's amyloid beta-peptide aggregation. Angewandte Chemie International Edition 54:8217-8221 DOI 10.1002/anie.201411606.

Teraoka H, Dong W, Hiraga T. 2003. Zebrafish as a novel experimental model for developmental toxicology. Congenital Anomalies 43:123-132

DOI 10.1111/j.1741-4520.2003.tb01036.x.

Terrill JR, Radley-Crabb HG, Iwasaki T, Lemckert FA, Arthur PG, Grounds MD. 2013. Oxidative stress and pathology in muscular dystrophies: focus on protein thiol oxidation and dysferlinopathies. FEBS Journal 280:4149-4164 DOI 10.1111/febs.12142.

Turki A, Hayot M, Carnac G, Pillard F, Passerieux E, Bommart S, Raynaudde Mauverger E, Hugon G, Pincemail J, Pietri S, Lambert K, Belayew A, Vassetzky Y, Juntas Morales R, Mercier J, Laoudj-Chenivesse D. 2012. Functional muscle impairment in facioscapulohumeral muscular dystrophy is correlated with oxidative stress and mitochondrial dysfunction. Free Radical Biology and Medicine 53:1068-1079 DOI 10.1016/j.freeradbiomed.2012.06.041.

Willett WC. 2006. The Mediterranean diet: science and practice. Public Health Nutrition 9:105-110.

Yen G-C, Chen H-Y. 1995. Antioxidant activity of various tea extracts in relation to their antimutagenicity. Journal of Agricultural and Food Chemistry 43:27-32 DOI 10.1021/jf00049a007.

Zakharova V, Dib C, Saada YB, Vassetzky Y, Galkin I, Chernyak B, Popova E. 2016. Uncoupling of oxidative phosphorylation and antioxidants affect fusion of primary human myoblasts in vitro. Biopolymers and Cell 32:111-117 DOI 10.7124/bc.000913.

Zammit PS, Golding JP, Nagata Y, Hudon V, Partridge TA, Beauchamp JR. 2004. Muscle satellite cells adopt divergent fates: a mechanism for self-renewal? Journal of Cell Biology 166:347-357 DOI 10.1083/jcb.200312007.

Zhu CH, Mouly V, Cooper RN, Mamchaoui K, Bigot A, Shay JW, Di Santo JP, ButlerBrowne GS, Wright WE. 2007. Cellular senescence in human myoblasts is overcome by human telomerase reverse transcriptase and cyclin-dependent kinase 4: consequences in aging muscle and therapeutic strategies for muscular dystrophies. Aging Cell 6:515-523 DOI 10.1111/j.1474-9726.2007.00306.x.

Zon LI. 1999. Zebrafish: a new model for human disease. Genome Research 9:99-100 DOI 10.1101/gr.9.2.99. 